EstAg 29 (1994) 529-576

\title{
De nuevo sobre la guerra y la paz
}

SUMARIO: I. Introducción 1) La justificación de la guerra 2) La guerra y la paz.- II. La teoría agustiniano-tomista de la guerra 1) Teoría agustiniana 2) Teoría tomista.- III. La Escuela salmantina del XVI.- IV. El arte de la guerra maquiavélico y el estado de lucha hobbesiano.- V. La paz y el Derecho internacional delvecchiano.- VI. Guerra y paz en la actualidad 1) En la Constitución española de 1978 2) En la Iglesia Católica.

I.1) Hoy en día, el tema de la violencia se ha impuesto en las conversaciones habituales al encontrarse en el centro de las preocupaciones políticas, sociales, económicas y jurídicas ${ }^{1}$. La violencia se descubre facilmente en el ámbito de las relaciones internacionales, bajo la forma de guerra o de guerrillas y, en muchas otras ocasiones, la encontramos en el terrorismo político y en la persecución ideológica. Incluso para algunos, los que podríamos calificar de "pesimistas", no existe ninguna diferencia relevante entre la violencia de nuestros días y la del pasado. Consideran éstos que la violencia ha acompañado al hombre a lo largo de su historia y que lo único que cambia son las formas y los instrumentos con los que se actúa. Ven imposible liberarse de la violencia por ser ésta inseparable de la condición humana y la consideran un puro hecho natural ${ }^{2}$.

1. Es este último ámbito, el jurídico, y más concretamente, el jurídico-filosófico, el que utilizaremos como instrumento en el presente estudio acerca de la guerra y la paz. Ciertamente, no somos pioneros en esta investigación, como demuestran los numerosos trabajos ya existentes al respecto (a modo de ejemplo y como obra colectiva se puede citar Derecho y paz. Actas del I Congreso de la Sociedad Española de Filosofía Jurídica y Social. Madrid, C.S.I.C., 1966; también, Orden social y violencia. Persona y Derecho. Universidad de Navarra, Eunsa, 3(1976); y Derecho, paz y violencia. Anuario de Filosofía del Derecho. Madrid, Nueva Epoca, 2 (1985)), pero no hemos podido sustraernos a la tentación, dadas las circunstancias actuales de "guerra deshumanizada" que se está llevando a cabo en lugares no muy lejanos, de volver la vista atrás en la historia e ir reconstruyendo y recordando los principios jurídicos que, básicamente, deben acompañar a toda guerra.

2. Cfr. COTTA, Sergio, Perchè la violenza? Una interpretazione filosofica. L'Aquila, Japadre Editore. 1978, pp. 7-12. (También en versión española: Trad. por Tomás Melendo, Las raíces de la violencia, Universidad de Navarra, Eunsa,1987, pp. 11-15). 
Otras opiniones no son tan pesimistas -como la de Sergio Cotta-, al considerar que la historia no deja de ofrecernos ejemplos de "flujos " y "reflujos", corsi y ricorsi diría Vico, entendiendo que en el "corso" (antiviolento) se produce un progresivo" avance en la lucha contra la violencia y, después, en el "ricorso" (della violenza) le sucede un rápido retroceso con el consiguiente triunfo de la violencia ${ }^{3}$, y así sucesivamente.

El tema de la violencia conduce inevitablemente al de la guerra ${ }^{4}$. Y, como si de los engranajes de una cadena se tratara, a su vez ésta resulta difícil separarla de la política ${ }^{5}$. Carl von Clausewitz afirmaba que la guerra es la continuación de la política por otros medios, preguntándose si sólo cabía considerar la guerra como si se tratara del instrumento de una determinada política ${ }^{6}$. Max Weber destacaba la relación existente entre política y violencia, al considerar la política como la dirección o, la influencia sobre la dirección, de una asociación política, es decir, en nuestro tiempo, de un Estado. A su vez, dicho Estado sólo será definible sociológicamente por referencia a un medio específico que él, como toda asociación política posee: la violencia física. Ciertamente, Weber no consideraba la violencia ni como el medio natural ni como el único medio de que el Estado pueda valerse, pero sí como su medio específico ${ }^{7}$.

Además de la versión de los "pesimistas", S. Cotta nos presenta otras opiniones: la que denomina apocalíctico-soteriológica, que considera que la violencia actual resulta nueva ya que ataca el pasado con una furia destructiva, total, tratando de presentar una violencia redentora. Y, otra tercera, la que califica de optimista-activista. Para ésta, la violencia de nuestros días es ciertamente mayor que la del pasado pero podría obedecer a una crisis de transformación (Ibidem, pp. 10-14. Las raíces de la violencia, pp. 16-20).

3. Cfr. Op. cit., p. 14. (Las raíces de la violencia p. 21)

4. Así por ejemplo S. Cotta, bien sea en los corsi o en los ricorsi, diferencia tres sectores claves dentro de la violencia: el de las relaciones civiles, el de las relaciones políticas y el de las relaciones bélicas internacionales.

5. Alvaro D'Ors cita una serie de causas que, a su juicio, provocan esa correlación entre guerra y política. En lo que se refiere al mundo clásico, observa que ello deriva de la habitual identidad, en aquella época, entre el jefe militar y el jefe político, identidad que se sigue dando en nuestros días incluso en Estados democráticos. Una razón más profunda de la correlación entre guerra y poder político la sitúa en la esencia del poder: "La política es, quiérase o no, una manifestación del poder social que mana de la comunidad a la vez que la configura, y, como tal poder, presupone la fuerza, una fuerza física social que defiende su independencia o su expansión natural en la ampliación de su dominio, es decir, como fuerza bélica. En este sentido, podría decirse del Estado que su último núcleo vital imprescindible está en la exclusiva de la fuerza militar. Porque todas las otras funciones que el Estado asume, como la economía o la instrucción, el fomento de las artes o el mantenimiento de las comunicaciones, incluso la misma legislación y administración de justicia, pueden concebirse como desconcentradas y ejercidas por entes no estatales, por ejemplo, regionales; pero el poder militar, ese sí que no se concibe desvinculado del Estado sin anular con ello la existencia del Estado mismo" (Ensayos de teoría política. Pamplona, Eunsa,1979, p. 34).

6. Cfr. De la guerra. Introd. de Piere Naville. Trad. de R.W de Setaro y Bernardo Muniesa. Barcelona, Mateu, 1972, p. 9.

7. Cfr. Politik als Beruf, Wissenschaft als Beruf. Citamos por: El político y el científico. Trad. de Francisco Rubio Llorente. Introd. Raymond Aron. Madrid, Alianza Editorial, 1988, pp. 81-82. 
Las relaciones entre estas diferentes realidades: violencia, guerra, política y Estado, han provocado, a lo largo de la historia, numerosos conflictos y, desgraciadamente, muchos de caracter violento y bélico. Con todo, quien se haya ocupado de la historia de la guerra y de su justificación llegará a la conclusión de que, en la mayoría de los casos, el hombre ha rechazado la guerra como un fin en sí mismo y la ha considerado como un medio para la consecución de la paz. Surge así el problema de la justificación de la guerra, de analizar cuáles son las causas y motivos que pueden hacer que una guerra se convierta en legítima o justa, cuestión que ha ocupado un lugar privilegiado en la reflexión filosófico política ${ }^{8}$ y que parece, aún no ha logrado un acuerdo unánime de todos los pueblos para conseguir desterrar definitivamente esa terrible realidad: la guerra ${ }^{9}$.

Se ha llegado a argumentar que el hombre, desde que vive en sociedad, ha necesitado de la herramienta bélica para su supervivencia. E incluso, se ha repetido que esta conducta no ha provocado la desparición de la humanidad sino que, por el contrario, ha dado lugar a una progresiva y continua superación, luchando "desde el miedo contra el miedo". De ahí que se considere que la "capacidad de disuasión" -en nuestros días por ejemplo, mediante la necesidad de armarse- para rechazar al enemigo se convierte así, en una especie de ley natural que ha de cumplirse irremediablemente ${ }^{10}$.

8. Como afirma Alfonso Ruiz Miguel : "Una de las distinciones tradicionales en la teoría jurídica y moral de la guerra es la que diferencia entre las reglas del ius ad bellum, o derecho a la guerra, y las del ius in bello, o derecho en la guerra. Mientras el primer tipo de reglas responde a la pregunta por la legitimidad o la legalidad de su iniciación, participación o intervención de un grupo político en la guerra, el segundo tipo se refiere a las conductas legítimas o legales dentro de una guerra ya en curso. Muy sintéticamente, el ius ad bellum intenta decir por qué se puede hacer la guerra y el ius in bello, en cambio, cómo se debe combatir. Ambos conjuntos normativos contienen y aducen reglas de justificación e injustificación de caracter jurídico o moral, sin aludir en principio a las reglas de la estrategia" (La justicia de la guerra y de la paz. Madrid, Centro de Estudios Constitucionales, 1988, p. 87).

Es evidente que las doctrinas sobre la justicia de la guerra han constituído un tema profusamente debatido a lo largo de la tradición del pensamiento filosófico, jurídico y político. La respuesta a cuestiones como: ¿para qué sirven las guerras? ¿por qué se hacen las guerras? ¿qué conducta puede adoptarse en las guerras?, etc. han sido variadas. A. Ruiz Miguel nos ofrece un esquema clasificatorio de las principales actitudes, diferenciando el belicismo absoluto (nihilismo, providencialismo, finalismo histórico) y el belicismo relativo (causa justa y guerra revolucionaria) del pacifismo relativo (legítima defensa) y del pacifismo absoluto (pacifismo político, escéptico, consecuencialista y radical de no violencia). Como se observa, es en el belicismo relativo donde acoge la tesis de la iusta causa como uno de los requisitos fundamentales de la guerra justa (Cfr. Op. cit., pp. 87-107).

9. Lamento que compartimos con Albert Calsamiglia, expresado en su cuidado estudio acerca de la justificación de la guerra (Cfr. La justificación de la guerra. En: "Sistema" 52 (1983) p. 40).

10. Cfr. HERRERA FLORES, Joaquín, Presupuestos para una consideración de la paz. En: “A.F.D.”. T.II (1985) pp. 107-108. 
Ello obedece a que no todas las líneas fundamentales de pensamiento de la Filosofía de la historia han considerado negativamente la guerra ${ }^{11}$. La guerra ha tenido un importante valor en la historia de la humanidad para algunos autores, tales como Heráclito ${ }^{12}$ y C. Schmitt, que veían en la guerra un estado natural del hombre y que incluso, como apunta Bobbio, pudiera significar un factor de progreso moral, cívico y técnico ${ }^{13}$. Esta es la actitud también mantenida por Maquiavelo para quien la guerra era el principio supremo de la política ${ }^{14} \mathrm{o}$, desde diferentes supuestos, por Hegel, para quien la guerra era una especie de "Juicio de Dios": cuando las voluntades soberanas no lograban llegar a un entendimiento, la controversia no podía decidirse sino a través de la guerra ${ }^{15}$.

Pero realmente ¿qué es la guerra? La manifestación más extrema de la violencia la constituye la guerra. A ésta se llega cuando la violencia adquiere un cuerpo de organización y afecta a un grupo social amplio ${ }^{16}$. Sabemos que una mera riña entre individuos no puede considerarse como tal pero sí la lucha entre comunidades políticas. Como veremos, Santo Tomás considera que una guerra es justa si es dictada por la autoridad del príncipe por cuyo mandato se ha de hacer la guerra. "No corresponde esto a la persona privada porque puede exponer su derecho ante juicio de superior..., pues estando confiado el cuidado de la república a los príncipes, les atañe defender el interés público de la ciudad, del reino o de la provincia" ${ }^{17}$. Por su parte, Clause-

11. Así lo ha advertido Alberto Montoro Ballesteros en su sugerente trabajo acerca de la guerra (Cfr. Reflexiones sobre el problema actual de la guerra y de la paz internacional. En: “A.F.D.”. T.II (1985) pp. 164-165).

12. "La guerra es el padre y el rey de todas las cosas; a unos los muestra como dioses y a otros como hombres, a unos los hace esclavos y a otros libres". (Fragmento 53. En: "Los Filósofos presocráticos”. $2^{a}$ ed., versión española de Jesús García Fernández. Gredos,1987, p. 282).

13. Son teorías que consideran la guerra como un mal necesario o un bien-medio para alcanzar un bien-fin (Cfr. BOBBIO, Norberto, Il problema della guerra e le vie della pace. Il Mulino, 1979. Citamos por: El problema de la guerra y las vías de la paz. Trad. de Jorge Binaghi. Gedisa, pp. $67 \mathrm{ss})$.

14. "Debbe, adunque, uno principe non avere altro obietto né altro pensiero, né prendere cosa alcuna per sua arte, fuora della guerra e ordini e disciplina di essa: perché quella è sola arte che si espetta a chi comanda; ed è di tanta virtù, che non solamente mantiene quelli che sono nati principi, ma molte volte fa gli uomini di privata fortuna salire a quel grado; e, per adverdo, si vede che è principi, quando hanno pensato più alle delicatezze che alle armi, hanno perso lo stato loro. E la prima cagione che ti fa perdere quello, è negligere questa arte; e la cagione che te lo fa acquistare, è lo essere professo di questa arte" (Il Principe, cap. 14. En: "Tutte le Opere". A cura di Mario Martelli. Sansoni Editore, Firenze, 1971, pp. 278-279).

15. Cfr. FRIEDRICH HEGEL, Georg Wilhelm, Gundliniem der Philosophie des Rechts oder Naturrecht und Staatswisenschaft im Grundise. Nit einem vorwort von Eduard Hans 4 aufl., Stuttart-Bad cannstatt, Friedrich Frommann Verlag, 1964, parágrafo 334, p. 443.

16. Cfr. SORIANO, Ramón, La paz y la constitución española de 1978. En: “A.F.D.”.T.II (1985) p. 140.

17. Summa Theologiae, $2-2$ q.40 a.1. Suma Teológica de Santo Tomás de Aquino. Texto latino de la ed. crítica Leonina. Trad. y anot. de comisión presidida por Francisco Barbado Viejo. T.VII, introd. de Teófilo Urdanoz. Madrid, B.A.C., 1964, p. 1075. 
witz identifica la guerra con un duelo "la guerra no es otra cosa que un duelo en una escala más amplia", y la fuerza física es el medio de la guerra para imponer nuestra voluntad al enemigo ${ }^{18}$.

Tanto Santo Tomás como Clausewitz, que se han ocupado de la guerra en épocas distintas y que parten de concepciones diferentes, coinciden en entender que sólo existen guerras allí donde existen comunidades políticas independientes con una autoridad determinada. El derecho de hacer la guerra no corresponde al individuo sino que corresponde a la autoridad. La guerra sólo puede darse en el caso de que existan intereses colectivos contrapuestos. A pesar de este punto en común, la finalidad de estos dos autores es diversa pues Santo Tomás pretende averiguar cuáles son las condiciones necesarias para que una guerra sea justa, intentando justificar la existencia de determinadas guerras. Clausewitz por su parte, no se plantea el problema de la justificación: no quiere valorar las guerras sino describir las guerras tal como son ${ }^{19}$.

Si bien resaltaremos cuáles han sido esas condiciones que se han enumerado a lo largo de años de reflexión filosófico-política, conviene destacar que para algunos teólogos y moralistas no puede hablarse de guerra legítima y apuntan por ello, la necesidad de elaborar un nuevo replanteamiento y crítica de la doctrina del bellum iustum ${ }^{20}$. Entre las insuficiencias y limitaciones de la "teoría de la guerra justa" se han señalado, entre otras, la dificultad de distinguir entre causa justa e injusta (generalmente, cada una de las partes contendientes en la guerra considera su propia causa como justa); la de que en la guerra no decide un tercero imparcial sino que cada una de las partes en pugna se toma la justicia por su mano; la de que la guerra no garantiza el triunfo de la justicia (en la guerra vence quien tiene más fuerza, no quien

18. Cfr. Op. cit., pp. 37 ss.

19. Cfr. CALSAMIGLIA, Albert, Op. cit., pp. 29-30.

20. N. Bobbio se pregunta si existen aún guerras justas. Para responder a esta cuestión diferencia entre dos conceptos: legitimidad y legalidad de la guerra. La legitimidad es un requisito de la titularidad de un derecho; la legalidad es un requisito del ejercicio de un derecho. El juicio de legitimidad de la guerra corresponde al justo título (la iusta causa) por el que se emprende; el juicio de legalidad corresponde exclusivamente al ejercicio o conducta de la guerra. Los dos juicios se hallan en planos diversos y son independientes entre sí de forma que pueden diferenciarse cuatro tipos de guerra: legítima y legal, legítima e ilegal, ilegítima y legal, ilegítima e ilegal.

Trasladando estos planteamientos a la situación actual, considera Bobbio que el ius belli ha sido desquiciado por la guerra moderna. Los cuatro límites a los que en general se halla sometida la guerra [1. respecto a las personas (distinción entre beligerantes y no beligerantes); 2. respecto a las cosas (individuación de los objetivos militares); 3 . respecto de los medios (prohibición de usar armas particularmente destructivas y homicidas); 4. respecto de los lugares (delimitación de las zonas de guerra)] no serán respetados si se produce una guerra atómica. De ahí que considere Bobbio que la guerra moderna se ubica fuera de todo posible criterio de legitimación y de legalización (Cfr. El problema de la guerra y las vías de la paz. Gedisa, pp. 56-50). 
tiene razón); y, por último, que la guerra constituye un recurso "malo" en la medida en que provoca muertes y desastres de orden material y moral ${ }^{21}$.

A pesar de los diversos intentos por encontrar, a lo largo de la historia, una solución a los conflictos de forma no violenta, S. Cotta ha llegado a señalar que el hecho verdaderamente característico de nuestro tiempo es el de la exaltación de la violencia. Defiende que hasta el siglo XIX, si se investiga a lo largo de la historia, no se encuentra ni una huella consistente de semejante exaltación. La violencia podía reconocerse como algo inevitable, como una realidad que había que soportar pero no se la consideraba como algo positivo. Por otra parte, plantea el dilema de que si se desea eliminarla, hay que recurrir a ella, ya que resulta difícil suprimir la violencia sin hacer, a la vez, uso de la misma ${ }^{22}$.

2) La suspensión práctica de la coexistencialidad esencial que debe darse entre todos los hombres y pueblos es la que suele provocar la guerra. Se trata del crecimiento de la diversidad entre los sujetos hasta llegar a convertirlos en antagónicos; la diversidad se transforma en absoluta alteridad y la diversidad rompe ese sustrato necesario para co-existir. Las causas de las guerras, materialmente, pueden ser muy variadas y diversas, pero practicamente siguen este esquema formal descrito. Y esta co-existencia puede referirse a cualquier tipo de existencia (en cuanto nación, Estado, clase social, religión, etc.) ${ }^{23}$.

Algunos sectores coinciden en señalar que el miedo a la guerra actúa como la principal causa del amor a la paz $^{24}$. En este contexto, la paz es valorada positivamente en la medida en que significa la negación de la guerra ${ }^{25}$.

21. Cfr. MONTORO BALLESTEROS, Alberto, Op. cit., pp. 174-175.

22. Cfr. COTTA, Sergio, Op. cit., pp. 21-23. (Trad. española, pp. 32-34).

23. Cfr. CRUZ PRADOS, Alberto, Para un concepto de "guerra" de una filosofía de la "paz”. Actualidad del pensamiento de Vitoria. En: “A.F.D.". T.II (1985) p. 110.

24. Cfr. COTTA, Sergio, Dalla guerra alla pace. Milano, Rusconi, 1989.

25. "La experiencia, tanto personal como histórica, nos muestra la regular alternancia entre paz y guerra. Una situación de paz nunca es perpetua; según se prolonga en el tiempo aparecen elementos discordantes y disconformes para los que el orden existente no resulta adecuado, justo; el crecimiento de este desorden relativo, de esta parcial disconformidad e intranquilidad, puede terminar en ruptura violenta, en situación de guerra. A su vez, ninguna guerra es tan "total", tan absoluta, que no permita la existencia de "paces" limitadas, de sectores o elementos parciales en paz; tampoco es definitiva: pronto, antes o después, aparecerán elementos que actuarán hacia la consecución de la paz; toda guerra termina en nueva paz" (DELGADO PINTO, José, La virtualidad del derecho como medio para la consecución de la paz. En: "Derecho y paz. Actas del Primer Congreso de Filosofía del Derecho". Madrid, Instituto de Estudios Jurídicos y C.S.I.C (1964) p. 29).

J. Delgado Pinto hace especial hincapié en resaltar el papel fundamental que desarrolla el derecho como medio para la consecución de la paz: "Sólo la paz social, no la paz interior del hombre, puede ser resultado y objetivo directo del Derecho. Pero aun siendo su resultado directo, la paz social no puede ser el objetivo primario del derecho, sino sólo consecuencia de su obje- 
Conviene sin embargo tener presente que estas dos reducciones, por una parte la de la paz a no-guerra y, por otra, la de la guerra a pura violencia, se implican mutuamente. De ahí que un adecuado tratamiento de la guerra deba tener presente no sólo las consecuencias y los medios de ésta, sino también y especialmente, sus causas y sus fines ${ }^{26}$.

De ahí que si hablar de violencia conduce inexorablemente al tema de la guerra, también hablar de paz ${ }^{27}$ conlleva el tratar de la defensa y, a su vez ésta, conduce necesariamente a la aceptación de la guerra. Así, Bobbio afirma que no existe una auténtica filosofía de la paz sino una filosofía de la guerra ${ }^{28}$. Conviene tener presente que querer la paz no es lo mismo -al menos no únicamente- que temer la guerra aunque sí exija una lucha contra las causas de la guerra ${ }^{29}$.

Sea como fuere, parece que en ninguna época de la historia como la que estamos viviendo se ha apreciado tanto la $\operatorname{paz}^{30}$ y denostado la guerra: $\mathrm{Y}$ no ha sido la proliferación de los movimientos pacifistas lo que ha contribuido a esta situación sino especialmente la confianza en el derecho y en la capacidad de los organismos internacionales. Con todo, el factor que puede haber

tivo o fin primario que es la implantación del orden social justo; la paz por sí no puede determinar directamente el contenido del orden jurídico. El Derecho no es igualmente eficaz para producir cualquier paz social; sólo es fundamentalmente eficaz para conseguir aquellas "paces sociales" que únicamente exigen la ausencia de conflictos violentos o arbitrarios, que se satisfacen con la segura determinación de la posición respectiva de los miembros del grupo y de sus posibilidades y formas de acción; (...) El Derecho resulta ser un medio muy limitado para producirla y garantizarla (la paz); precisa para llevar a cabo con éxito tal función de la ayuda y complemento de otros órdenes normativos y vehículos de integración: de la moral, de otros tipos de usos y formas de relación, de la amistad y el amor entre los hombres" (Ibidem, pp. 45-46).

26. Cfr. CRUZ PRADOS, Alberto, Op. cit., p. 107.

27. Alvaro D'Ors se ha interesado por clarificar el sentido de "paz" en relación con la victoria. Cuando un contendiente consigue dominar al otro y le obliga a deponer las armas, entiende que se trata de una rendición; si la guerra ha sido legítima, este éxito de las armas debe llamarse victoria, una victoria legítima. Por el contrario, cuando no se llega a ese extremo sino que, por iniciativa de un contendiente o de los dos a la vez, se produce un arreglo de transacción que evita el desarrollo ulterior de la guerra, considera que hay paz (Cfr. De la guerra y la paz. Madrid, Rialp, 1954, p. 86).

28. Cfr. BOBBIO, Norberto, El problema de la guerra y las vías de la paz. Barcelona, Gedisa, 1982, p. 161.

29. Cfr. LUCAS MARTIN, Javier de, La noción de defensa y la crisis de legitimidad. En: "A.F.D.". T.II (1985) p. 78.

30. A pesar de que se suele calificar la paz como "utópica" y la guerra como "realista", no puede dejar de apuntarse una cierta dosis de realismo en la paz, como la que entraña el ser conscientes de las dificultades que, en la práctica se presentan, en el proceso de consecución de la paz. Así por ejemplo, Pedro de Vega ha señalado seis principalmente: los desajustes económicos y los conflictos de intereses, el totalitarismo, el nacionalismo, el irracionalismo, la tecnificación y, por último, la carrera de armamentos (En torno a la paz y algunas dificultades que obstaculizan su proceso. En: “Derecho y paz. Op. cit.," pp. 245-256). 
resultado decisivo es el caracter de destrucción total que la guerra podría presentar en la actualidad ${ }^{31}$.

En los últimos tiempos, en el ámbito de las relaciones internacionales, se ha producido un sometimiento de la guerra a un determinado derecho. No podemos olvidar sin embargo que, a lo largo de la historia, la guerra se ha encontrado en una posición ambigua, oscilando entre dos polos: para algunas corrientes ha sido concebida como sujeta a las leyes morales y a las normas jurídicas de derecho natural, tal y como defendían, entre otros, San Agustín, Santo Tomás y la Escuela salmantina del Quinientos. Para otros ha sido considerada como una realidad natural e inevitable, sin estar sujeta a ninguna reglamentación que no fuera la utilidad política, la estrategia, las razones de Estado, etc. Baste recordar a los grandes artífices clásicos de la guerra como Aníbal, César, o Napoleón. En estos casos, la guerra es interpretada como una realidad disciplinada, no a las reglas de derecho sino a la inteligencia que la adapta a la relación de medio a fin ${ }^{32}$.

La balanza parece que se ha inclinado más en el segundo sentido, al estar en juego, en la casi totalidad de los casos, los intereses políticos (no puede olvidarse que, para la política, la guerra es, en muchas ocasiones, la "partida decisiva") ${ }^{33}$. Con todo, no puede restarse mérito a quienes han luchado por un desarrollo riguroso de una teoría científica acerca del ius belli, tal y como hicieron los teólogos juristas españoles del XVI.

Es esto lo que intentamos destacar en el presente estudio, haciendo un breve recorrido histórico y deteniéndonos en aquellas doctrinas, las más relevantes y significativas que han marcado un hito en la construcción de la teoría de la guerra, a la vez que resaltaremos las que han defendido una guerra legítima.

II. La violencia y su manifestación en conflictos armados ha sido un común denominador a lo largo de la historia. Baste observar en el mundo

31. Baste recordar el caso de la "guerra del Golfo", en Kuwait, para apreciar el temm con respecto a los nuevos instrumentos de guerra, tales como las armas químicas, etc. con sus efectos devastadores no sólo sobre los combatientes sino también sobre la población civil, las generaciones venideras, el ecosistema, etc.

Asimismo, más recientemente, la realidad bélica yugoslava ha golpeađo esa puerta jurídica y de "buen orden internacional" bajo la que nos hemos refugiado en los últimos tiempos, poniendo de evidencia que no está todo hecho con respecto a la guerra y al derecho. ¿De qué sirve en el terreno práctico la normativa del Derecho internacional o todo lo que se ha escrito acerca de los derechos humanos así como todos los convenios ratificados en esta materia? Surge la cuestión de si lo que se necesita es una institución fuerte con poder sancionador en aquellos casos en que no se cumpla el derecho porque parece que sólo se entiende el lenguaje del miedo a la sanción, al castigo.

32. Cfr. COTTA, Sergio, Op. cit., p. 35. Las raíces de la violencia, p. 51.

33. Cfr. Ibidem, p. 36. Las raices de la violencia, p. 52. 
griego ${ }^{34} \mathrm{y}$, posteriormente en el mundo romano ${ }^{35}$, su respectiva concepción de la guerra como algo natural. Las guerras antiguas fueron con frecuencia devastadoras e, incluso, de exterminio. La institución de la esclavitud supuso un avance en la humanización de la guerra en cuanto ofreció una razón para conservar la vida del vencido. La lucha contra los bárbaros hacía posible conseguir esclavos, factor que potenciaba su economía, a la vez que permitía extender sus dominios a otros territorios. La llegada del cristianismo provocará un profundo cambio en las estructuras de estas culturas.

1) El cristianismo primitivo era contrario a la guerra, "no se debía responder con violencia a la violencia" y, "al que nos hacía mal había que responder ofreciéndole la otra mejilla"... aunque propiamente no existía una

34. Como señala Eustaquio Galán y Gutiérrez, conviene que la ciencia política tenga en cuenta las concepciones de los pensadores presocráticos ya que "los primeros filósosfos presocráticos de la naturaleza, saturados de experiencia histórica, explicaron la naturaleza por analogía con la sociedad, hasta el punto de que la concepción del cosmos que en la filosofía de aquella época prevalece tiene sus orígenes en la aplicación al mundo físico de las ideas y de los principios que previamente se había formado el saber acerca de la sociedad y del mundo humano" (La guerra inexorable. En: "Revista Española de Derecho Internacional". Madrid, C.S.I.C., vol. XIV, 1-2 (1961) pp. 98; Vid. también vol. III, 2 (1950) pp. 335-362).

Así, por ejemplo, Empédocles reserva en su concepción del mundo un lugar necesario a la guerra. Empédocles entiende constituida la materia cósmica por cuatro elementos principales: la tierra, el aire, el agua y el fuego. A su vez, estos elementos inertes se combinan en nuevas formas en virtud de dos fuerzas contrarias: el amor y el odio. Son en la realidad éstas las dos fuerzas cósmicas más poderosas que hacen del acontecer una constante alternativa las situaciones de lucha y paz". Es Anaximandro en quien por primera vez aparece la idea (que luego pasará a ser pieza central del pensamiento de Heráclito) según la cual "la naturaleza es concebida como un campo de fuerzas o elementos contrapuestos, como una lucha: si el equilibrio entre los elementos que componen la realidad se rompe, entonces uno predomina sobre los demás, y de esta situación se originan desarmonías o injusticias que necesitan ser superadas o rectificadas. El acontecer de la naturaleza transcurre en forma de compensación entre sucesivos desequilibrios mutuos".

En Heráclito reaparece esta concepción polémica o antagónica de la realidad. A su juicio, la realidad no sólo es un ser estático ya que él la concibe como acontecer, como devenir, sino que además resulta en su estructura dominada por la oposición y contraste de todos sus elementos e implica como un movimiento polémico de fuerzas y principios contrarios. La lucha constituye así el principio generador de todas las cosas: "Todas las cosas vienen a la existencia y la abandonan por medio de la lucha". "La guerra es la madre y la reina de todas las cosas"... Para Protágoras, "la vida social, en su manifestación originaria, en vez de consistir en una situación de pacífica convivencia, habría sido, al contrario, un estado de lucha general de todos contra todos. Gracias al regalo de Zeus, el sentimiento de la justicia y de la recíproca tolerancia, fue posible la paz en el seno de la convivencia social, aunque siempre existía la amenaza de que podría ser alterada" (Ibidem, pp. 97-107).

35. Alvaro D'Ors señala que la guerra de los antiguos romanos tenía una profunda raíz ético-espiritual, manifestada por una parte, en su concepción de la guerra como un medio de asegurar el territorio y, por otra parte, en su particular bellum iustum. Porque el bellum iustum romano no es lo que hoy entendemos por guerra materialmente justa, sino una guerra ajustada a las conveniencias. Al lenguaje militar pertenece la expresión iter iustum, que es la "jornada 
auténtica doctrina sobre la guerra. Posteriormente, los cristianos sólo se cuestionaban el problema de la licitud de la participación personal en la guerra, especialmente en el caso del reclutamiento forzoso para las milicias. Más tarde, comienza a plantearse de una forma más global como licitud o ilicitud de la guerra para la moral cristiana.

San Agustín fue uno de los autores que contribuyó al cambio de rumbo del pensamiento cristiano con respecto a la guerra. El pesimismo antropológico que profesó el Obispo de Hipona le llevó a acentuar los efectos del pecado original en el sentido de que partía de una corrupción de la naturaleza misma. La teoría de la guerra agustiniana se refería en este sentido al enfrentamiento con las herejías, principalmente la de Pelagio. Este defendía la absoluta libertad de la voluntad del hombre, confiando en la bondad de la naturaleza humana no corrompida por el pecado. Afirmaba la posibilidad de obrar bien y de salvarse sin necesidad de la gracia divina ${ }^{36}$. San Agustín, frente a Pelagio, consideraba que el hombre era pecador desde Adán. Por ello, perdida la integridad original del hombre, sólo débilmente puede la naturaleza racional servir de norma de acción. De ahí que insista San Agustín en la necesidad de la estrecha subsunción en la ley divina revelada y, a la vez, la de que se acentúe el papel coercitivo y represivo del derecho humano en la vida concreta de la sociedad.

Por otra parte, se enfrenta al problema de la decadencia del Imperio Romano y a las causas que originaron esa decadencia. Existía una corriente de pensamiento que atribuía al cristianismo y a su moral de "no resistir al mal" la culpabilidad de esa decadencia. El Obispo de Hipona se plantea este problema y en una carta a Marcelino defiende la necesidad de la guerra: "un padre no pierde el amor paterno, aunque castigue a su hijo algo ásperamente. Se ejecuta lo que el niño rehúsa, aunque le duela, pues aún a la fuerza hay que corregirle con dolor... Con la victoria se logra utilidad para aquellos a quienes se quita la licencia de iniquidad. Porque no hay cosa más infeliz que la felicidad de los pecadores" ${ }^{37}$.

justa", la conveniente en las marchas militares. De ahí que aplicado a la guerra, ésta fuera justa cuando se hubieran observado en ella ciertas formalidades que demostraran su conveniencia, empezando por la formalidad de los auspicios (se trataba de una conveniencia utilitaria, pues esas consultas a la divinidad no se refieren a una justicia universal y objetiva sino a la conveniencia del nomem Romanum, de conformidad con la voluntad divina protectora constante de Roma (Cfr. Ensayos de teoría política. Pamplona, Eunsa,1979, pp. 49-50).

36. Pelagio, monje inglés, defendía la absoluta libertad de la voluntad humana, la bondad de la naturaleza humana, no corrompida por el pecado y, por consiguiente, la posibilidad de obrar bien y de alcanzar la salvación sin el concurso divino de la gracia. Esta tesis privaba al cristianismo de todo significado ya que si el hombre no ha sido corrompido por el pecado original, son inútiles la venida de Cristo y la redención, e igualmente los sacramentos, medios de la gracia, y la Iglesia, administradora de ellos.

37. Carta a Marcelino (núm. 138). Obras de San Agustín. Ed. bilingüe. T. XI, Madrid, B.A.C., 1953, p. 139. 
De ahí que frente a aquellos que pretendían fundamentar en la Sagrada Escritura un pacifismo absoluto, defienda San Agustín la licitud del servicio de las armas y la guerra. Y cita en apoyo de su tesis de la justificación de la guerra, algunos ejemplos evangélicos: "Si la disciplina cristiana condenase todas las guerras se les hubiera dado en el Evangelio este consejo saludable a los soldados, diciéndoles que arrojasen las armas y dejasen enteramente la milicia: En cambio, se les dijo: A nadie golpéis, a nadie calumniéis y contentaos con vuestra paga. Pues les mandó que se contentasen con la paga, sin duda no les prohibió la milicia" ${ }^{38}$.

Para San Agustín, la guerra será sólo legítima si es el único medio de hacer frente a la injusticia entre los pueblos. El derecho de la guerra es casi una manifestación del derecho de castigar, que corresponde a la autoridad y, en este caso, se ejerce contra los enemigos exteriores. Y, como después indicará Santo Tomás, por ser la guerra un acto de justicia punitivo, ha de promover siempre una paz ulterior más justa que la que había ${ }^{39}$. Mantener la paz es un asunto de voluntad, emprender la guerra es cuestión de necesidad ${ }^{40}$.

Considera el Obispo de Hipona que en numerosas ocasiones son las guerras justas las que contribuyen al crecimiento de los reinos. De ahí que su teoría de la guerra legítima haya de integrarse en el contexto de una concepción de la vida internacional fundada en la convivencia pacífica de pequeños pueblos cuyos deseo es una concorde vecindad, concordi vicinitate, y así habría en el mundo muchísimos reinos nacionales, como hay en la ciudad muchísimas casas de ciudadanos ${ }^{41}$. Postula San Agustín un pluralismo jurídico internacional preferible a un imperio universal bajo la dominación de un solo pueblo (no le era ajena la caída del Imperio Romano).

Por otra parte, en la doctrina agustiniana encontramos esbozada la idea de la comunidad internacional como pluralidad de Estados nacionales organizados entre sí. Ello parece deducirse de la triple gradación de sociedades naturales: domus, urbs, y orbis, que responden a exigencias naturales. Es significativo ese tertium gradum ponunt societatis humanae ${ }^{42}$ avanzado por el

38. Ibidem, p. 141.

39. De ahí que todos los guerreros intenten, mediante una guerra, llegar a una paz más perfecta de la que antes había: "Et propter hoc omnes bellantes quaerunt per bella ad pacem aliquam pervenire perfectiorem quam prius haberent" (Summa, 2-2 q.29, a.2, p. 922).

40. La paz es, por consiguiente, aspiración suprema de los seres: "Quandoquidem et ipsi qui bella volunt, nihil aliud quam vincere volunt: ad gloriosam ergo pacem bellando cupiunt pervenire. Nam quid est aliud victoria, nisi subiectio repugnantium?" (De Civitate Dei, lib. XIX, cap. 12. Obras de San Agustín. Ed. bilingüe. T. XVII, $2^{\mathrm{a}}$ ed., preparada por José Morán, Madrid, B.A.C., 1964, p. 481).

41. "(...) ac sic felicioribus rebus humanis omnia regna parva essent concordi vicinitate laetantia: et ita essent in mundo regna plurima gentium, ut sunt in urbe domus plurimae civium" (De Civitate Dei, lib. IV, cap. 15, p. 212).

42."Post civitatem vel urbem sequitur orbis terrae, in quo tertium gradunt ponunt societatis humanae, incipientes a domo, atque inde ad urbem, deinde ab orbem progrediendo venientes" (De Civitate Dei, lib. XIX, cap. VII, p. 474). 
Obispo de Hipona y que después reelaboraría Francisco de Vitoria. Su descripción de la civitas caelestis permite apreciar su defensa de la diversidad de naciones, con las peculariedades características de cada una de ellas (leyes, lenguas, institutos, etc.) sin que considere que ello pueda afectar al mantenimiento de la paz terrena ${ }^{43}$.

En definitiva, hay que considerar que la teoría de la guerra de San Agustín resulta un tanto imprecisa. Pretende con los argumentos expuestos, demostrar que la doctrina cristiana no había sido la causa de la decadencia de Roma y que la doctrina evangélica no prohibía ni el ejercicio de la guerra ni la legítima defensa. Las guerras se hacen justamente para deshacer las injurias. La guerra es concebida, por el Obispo de Hipona, como una especie de procedimiento judicial y como una expresión del derecho a castigar. Habrá que esperar a la Summa de Santo Tomás para encontrar una doctrina más elaborada acerca de la guerra ${ }^{44}$.

2) Al igual que la Escolástica recupera el pensamiento de la Patrística, Santo Tomás, siguiendo la doctrina agustiniana aunque en una línea más racionalista que voluntarista, sostiene que las leyes humanas obligan por su congruencia con la ley natural y se hace eco de las sugerencias de San Agustín en este ámbito. Una ley es ley en tanto que es justa, es decir, recta según la norma de la razón y, por ello, está de acuerdo con la ley natural, que es la primera norma de la razón. Una ley positiva que difiera en algo de la ley natural no sería una ley sino una corrupción de ley ${ }^{45}$. Tal afirmación implica-

En De Civitate Dei también se encuentran referencias a la sociedad humana: "unum ac singulum creavit, non utique solum sine humana societate deserendum, sed ut eo modo vehementius ei comendaretur ipsius societatis unitas vinculumque concordie (...)" (Ibidem, lib. XII, cap. 22, p. 701).

Añade que el hombre sabio sentirá verse obligado a declarar guerras justas, pues, si no fueran justas, no debería declararlas, y, por tanto, para él no habría guerras. La injusticia del enemigo, considera, es la causa de que el sabio declare guerras justas: "quia nisi iusta essent, ei gerenda non essent, ac per hoc sapienti nulla bella essent. I niquitas enim partias adeversae iusta bella ingerit gerenda sapienti: quae iniquitas utique homini est dolenda, quia hominum est, etsi nulla ex ea bellandi necessitas nasceretur" (De Civitate Dei, lib. XIX, cap. VII, p. 475).

Incluso advierte San Agustín que en muchas ocasiones resulta difícil distinguir al amigo del enemigo y que es fácil creer al amigo enemigo o al enemigo amigo. (Ibidem, lib. XIX, cap. VIII, p. 476). Nótese la dificultad que esto conlleva en lo que se refiere a su aplicación a la guerra justa.

43. "Haex ergo caelestis civitas dum peregrinatur in terra, ex omnibus gentibus cives evocat, atque in omnibus linguis peregrinam colligit societatem; non curans quid in moribus, legibus, institutisque diversum est, quibus pax terrena vel conquiritur, vel tenetur; nihil eorum rescindens, nec destruens, imo etiam servans ac sequens" (De Civitate Dei, lib. XIX, cap. XVII, p. 496).

44. Cfr. CALSAMIGLIA, Albert, Op. cit., p. 42.

45. "Unde omnis lex humanitus posita intantum habet de ratione legis, inquantum a lege naturae derivatur. Si vero in aliquo a lege naturale discordet, iam non erit lex sed legis corruptio" (Summa, 1-2 q.96, a.4, pp. 167-168). 
ba que no podían considerarse válidas las leyes injustas en la medida en que eran disconformes con una determinada concepción del derecho natural. Sin embargo, en otras ocasiones, el Aquinate no parece negar la existencia de las leyes injustas. Aun reconociendo su disconformidad con la ley natural, niega a las leyes injustas valor moral pero reconoce su validez jurídica. Las acepta como leyes y defiende que puedan obligar para evitar escándalos y desorden, propter vitandum sacandalum vel turbationem ${ }^{46}$ debiendo desobecer sólo las leyes contrarias a la ley divina-positiva.

Esta cuestión de la obediencia a la ley muestra un paralelismo con aquella otra de la obediencia al gobierno injusto, es decir, la resistencia a la tiranía. De ahí que también defienda Santo Tomás que es lícito rebelarse contra la misma, siempre y cuando esta rebelión no derive para los súbditos en un mal peor que la tiranía misma ${ }^{47}$. Si así fuera, aconseja desistir, debiendo conformarse los súbditos con ese gobierno tiránico y considerar que Dios tolera a los tiranos como castigo de los pecados de los hombres, como ya habían advertido anteriormente San Agustín y San Isidoro. La doctrina tomista muestra aquí esa desconfianza propiamente agustiniana en la naturaleza del hombre, esa consideración de pecador y, el correspondiente castigo.

Siguiendo esta misma línea agustiniana y sin introducir cambios significativos en lo esencial, desarrolla una teoría de la guerra justa más elaborada en su ya conocida Quaestio 40, en la Summa. Establece la exigencia de tres requisitos para considerar una guerra como justa, quod aliquod bellum sit iustum, tria requirentur. Primero, la autoridad del príncipe, auctoritas principis. En segundo lugar se requiere causa justa, causa iusta, es decir, ut scilicet qui impugnantur propter aliquam culpam impugnationem mereantur. Y, finalmente, se requiere que sea recta la intención de los combatientes, intentio bellantium recta: que se intente o se promueva el bien o que se evite el $\mathrm{mal}^{48}$. Matiza, dentro de las condiciones de licitud de la guerra, lo relativo a la autoridad legítima, entendiendo que puede ser la de cualquier entidad política y no sólo la del Emperador o la del Papa. La principal novedad de la teoría tomista de la guerra justa radica precisamente en su amplia difusión al haber sido introducida en la Summa y convertirse después ésta, en manual de estudio en escuelas y Universidades.

46. "Unde tales leges non obligant in foro conscientiae: nisi forte propter vitandum scandaIum vel turbationem, propter quodo etiam homo iuri suo debet cedere (...)" (Summma, 1-2 q.96, a.4, p. 185)."

47. “ (...) quod regimen tyrannicum non est iustum: quia non ordinatur ad bonum comune, sed ad bonum privatum regentis, ut patet per Philosophum, in III "Polit." et in VII "Ethic.". Et ideo perturbatio huius regiminis non habet rationem seditionis: nisi forte quando sic inordinate perturbatur tyranni patitur ex perturbatione consequenti quam ex tyranni seditiosus" (Summa, 2-2 q.42, a.2, pp. 1092-1093).

48. Summa, 2-2 q.40, a.1, pp. 1074-1076. 
El Aquinate ofrece algunas aportaciones a la doctrina del derecho de gentes y a la política internacional, llegando a admitir un ius gentium. Hay principios que aparecen en nuestra razón como necesarios para la convivencia de los pueblos y Estados, y que de hecho suelen ser observados por todos los pueblos. Así, se consideran universalmente inviolables los embajadores; se cuenta con que los tratados han de ser mantenidos; o que las mujeres y los niños e inocentes deben ser respetados en la guerra. Se trata del derecho natural que ofrece un diseño del derecho de gentes o internacional. Y, como para Santo Tomás el derecho no era una mera cuestión de fuerza, sino esencialmente un orden de razón ${ }^{49}$, se desvanece ante él la objeción de que tras el derecho de gentes no hay un poder que lo respalde y, por consiguiente, al no ser coactivo, no es verdadero derecho, así como también la dificultad de que un derecho así carezca de forma. Serán estas ideas tomistas acerca del derecho de gentes las que después desarrollarán la Escuela salmantina y el autor clásico del derecho de gentes, Hugo Grocio.

La teoría agustiniano-tomista de la guerra justa hay que encuadrarla en su marco adecuado: el de una sociedad confesionalmente cristiana y, de ahí que las guerras que se consideraran justas fueran prácticamente las encaminadas a defender el sacro Imperio o las emprendidas contra el infiel. Por otra parte, su contexto es teológico y habrá que esperar hasta la doctrina del XVI para encontar un ámbito más propiamente ético y jurídico ${ }^{50}$.

III. En el siglo XVI y XVII España ofrece, con la conquista de América, un foco de debates que dió origen a numerosas discusiones destacando, por sus fundamentadas teorías, la Escuela española del Derecho natural y de gentes o, más propiamente, la Escuela de Salamanca ${ }^{51}$, que intentará aplicar los principios generales de la moral cristiana y del derecho natural a la nueva problemática de su tiempo. En el orbe cristiano medieval, la guerra entre cristianos fue siempre considerada como un gran mal, como si se tratara de una guerra civil, sometida a numerosos requisitos. En cambio, la guerra contra el infiel se entendía en principio como una guerra justa ${ }^{52}$ en la que se

49. Summa, 1-2 q.90, a.3, pp. 39-41.

50. Cfr. OSUNA FERNANDEZ-LARGO, Antonio, El derecho de la paz en la escuela española. En: “A.F.D.”. T.II (1985) p. 198.

51. "Involucrada durante varıas décadas en la pomposa denominación de Escuela Española del Derecho natural y de gentes o también encubierta bajo el nombre genérico de Escolástica española, muy del agrado de la mentalidad del pasado régimen político y en gran medida tributarias ambas de la reivindicación de la Ciencia Española hecha en su juventud por Marcelino Menéndez y Pelayo, hoy parece ser que las aguas vuelven a su cauce natural, que nunca debió ser desbordado. En realidad, no hubo una Escuela española ni cosa que se le parezca, y lo que sí hubo fue una auténtica Escuela de Salamanca de universal renombre"(RODRIGUEZ MOLINERO, Marcelino, La doctrina colonial de Francisco de Vitoria, legado permanente de la Escuela de Salamanca. En: “A.F.D.”. T. VIII (1991) p.45).

52. Para Juan Ginés de Sepúlveda, un ejemplo indiscutible de guerra justa era en la que se luchaba contra los turcos. Sepúlveda, en su Demócrates alter y una vez convencido de que los 
admitían mayores licencias. Puesto que en el orbe cristiano el principio unificador básico era la fe común, de ahí que la religión fuera la principal causa de guerra justa. El descubrimiento de los nuevos territorios de ultramar plantea ${ }^{53}$, por vez primera, la legitimidad de las ocupaciones pacíficas y conquistas bélicas de los territorios americanos, con el consiguiente problema general de las relaciones y derechos de paz y de guerra entre los pueblos ${ }^{54}$.

Pocos años antes, Francisco de Vitoria, precursor de un nuevo orden internacional ${ }^{55}$, en su intento de configurar un diverso ius gentium, había recuperado la teoría de la guerra justa. Esta teoría ha de entenderse a la luz

cristianos pueden hacer la guerra, se plantéa si una guerra justa es una posibilidad realizable, si se puede hacer de acuerdo con el derecho natural. Como señala J.A. Fernández Santamaría, la posición de Sepúlveda en este tema es diáfana. ¿qué puede ser más natural que defender la vida propia y la de los amigos o impedir la injusticia que se hace contra nosotros, contra nuestros amigos y contra los seres inocentes? La guerra no está prohibida a los cristianos sino que por el contrario, tienen la obligación de servir en el ejército porque a todos los que forman parte de la sociedad civil les corresponde la obligación natural de defender esa sociedad y porque la guerra no es contraria a la ley divina cuando se lucha por una causa justa.

Continúa Fernández Santamaría afirmando que para Sepúlveda, la guerra justa, que nunca es deseable, será no obstante, un medio para conseguir una paz justa. De ahí que no considere la paz como un fin en sí mismo sino simplemente un medio para alcanzar un bien mayor: permitir que el hombre goce de forma ininterrumpida de sus capacidades aristotélicas como animal social y político. Las condiciones que señala Sepúlveda para afirmar que una guerra es justa son: 1) la que busca rechazar las injurias y evitar que la nación caiga en esclavitud. 2) la que busca el imperio sobre aquellos por cuyo bien se mira de modo que los bárbaros, mediante la verdadera religión se mantengan razonablemente dentro del cumplimiento del deber. 3) que se sometan al imperio heril aquellos que son dignos de tal condición como en aquellas naciones donde se dan hombres por naturaleza inclinados al mal, los cuales deben ser dominados y apartados de las injurias. (Cfr. The State, war and peace. Spanish Political Thouht in the Renaissance, 1516-1559. Cambrigde University Press, 1977. Citamos por la trad. española de J. Faci Lacasta, El Estado, la guerra y la paz. El pensamiento político español en el Renacimiento 1516-1559. Madrid, Akal,1988, pp. 217-222).

53. Para el tema de la justificación ética y jurídica de la conquista del Nuevo Mundo y el relevante papel desempeñado por la Escuela salmantina, nos remitimos a nuestro trabajo $L a$ Escuela de Salamanca y la acción ultramarina hispánica. La conquista de Nueva España. En: "Ciencia Tomista". Salamanca, T. 121, 1 (1994), pp. 79-112.

54. Conviene no olvidar que, ya antes de la actuación de los españoles en América, la empresa de la Reconquista como reocupación de territorios que antes fueron cristianos se tenía por incontestado argumento para usar las armas y la violencia hasta llegar a tal recuperación. Tal tipo de guerra, aún ofensiva, se tenía por plenamente justificada.

55. En el terreno teórico se pueden señalar casos aislados del recto concepto internacionalista. Ya hemos visto esbozada, en algunos textos del De Civitate Dei agustiniano, la idea de la comunidad.

Teófilo Urdánoz considera (Cfr. Síntesis teológico-jurídica de la doctrina de Vitoria. En: "Francisco de Vitoria. Relectio de Indis o Libertad de los indios". Ed. crítica bilingüe de L. Pereña y J.M. Pérez Prendes. Madrid, C.S.I.C, 1967, p. CVIII) que aunque Sto. Tomás no hubiera compartido la teoría medieval del dominio mundial del Papa y el Emperador, pudo vivir la culminación del orbis christianus sobre el que reconocía la supremacía indirecta del Papa en lo temporal, sin llegar a plantearse explícitamente el problema de la comunidad internacio- 
de los presupuestos fundamentales del pensamiento vitoriano ${ }^{56}$. Se había dado por supuesta la soberanía política de España sobre los pueblos ocupados pero quedaba por abordar el problema de los fundamentos jurídicos de aquel dominio político, o de la legitimidad de la conquista y colonización emprendidas.

Es Vitoria quien por primera vez plantea y soluciona sobre nuevos cauces jurídicos basados en una concepción universalista, la societas umani generis, la sociedad natural de todas las gentes. Su ius gentium es concebido como una parte del derecho natural, como aquél que la razón natural estableció entre todas las gentes, lo cual no impedía que la voluntad humana, expresa o tácita, diera además lugar, a un derecho de gentes positivo. Como consecuencia de la idea del totus orbis y de un derecho de gentes natural y positivo, defendía la existencia de un derecho fundamental de libre comunicación entre los pueblos, el ius communicationis, al que no cabía sustraerse sin justa causa llegando a imponerse, si fuera necesario, mediante el empleo de la fuerza ${ }^{57}$, y que aplicó para justificar la entrada de los españoles en el Nuevo Mundo, como pone de manifiesto en su relección De Indis, de $1538^{58}$.

La vigencia normativa del derecho natural es puesta por Vitoria en el mismo plano real del derecho estatal, y con mayor fuerza si cabe que éste. Lo prueba la fuerza coactiva con que lo declara respaldado, mayor aún que

nal, extendida a todos los pueblos del orbe. Sin embargo, en un texto, sí expresa la idea de una comunidad de todo el mundo, paralelo al régimen universal de la Iglesia en lo espiritual :"(...) sicut communitas provinciae includit communitatem civitatis, et communitas regni communitatem unius provinciae et communitas totius mundi communitatem regni" (in c., Supple. q.40 a 6).

56. Estos fluían de las grandes doctrinas antropológicas, morales y sociales de la Summa tomista en que se había formado y que después introdujo como fuente inmediata o texto de su enseñanza teológica: las características de la persona humana como espiritual, libre y con la dignidad como fuente de derechos, el dominio del hombre sobre la naturaleza, la igualdad de todos los hombres en sus prerrogativas básicas, la concepción del derecho natural como base de todo el orden humano de relaciones justas y su neta distinción del orden sobrenatural o propiamente cristiano (Cfr. URDANOZ, Teófilo, Op. cit., p. XLVII).

57. Es precisamente este nuevo derecho de gentes de F. de Vitoria el que criticó Alvaro D'ors, basándose en que la "neutralización" a que dió lugar la construcción vitoriana no era adecuada. La neutralización consistía en huir de los argumentos tradicionales para justificar nuestra misión en América e invocar el principio neutro del ius peregrinandi. El nuevo principio era neutro porque no se fundaba en un argumento de autoridad (ni en el poder imperial ni en el poder temporal) sino en una razón aparentemente sencilla: la de que todos los hombres debían tener libertad para viajar por todo el mundo y hacer el comercio sin impedimentos. Un principio así no requería, para ser admitido, ningún credo religioso determinado. El Derecho internacional dejó de plantearse sobre el terreno de la "comunidad del orbe católico" para especular con el concepto de "relación de las naciones": ésta fue la novedad introducida por Vitoria. Considera D'Ors que esta conclusión no se recibió entonces más que por el aspecto negativo, es decir, el neutralizante y alejado de toda intromisión religiosa en la ciencia del Derecho internacional (Cfr. De la guerra y de la paz. Madrid, Rialp, 1954, pp. 145-154).

58. VITORIA, Francisco de, Relectio De indis o libertad de los indios. Ed. crítica bilingüe de L. Pereña y J.M. Pérez Prendes. Madrid, C.S.I.C., 1967. 
para el derecho civil. Porque las "injurias" o transgresiones graves de estos derechos naturales de orden internacional llevan consigo, como sanción, otras tantas causas belli, las intervenciones y ocupaciones bélicas o diversas formas de guerra ofensiva, como queda ampliamente recogido en su Relectio de Iure Belli ${ }^{59}$, de 1539.

Su doctrina acerca de la guerra justa ha sido el punto de referencia obligado para enjuiciar éticamente las guerras de conquista de la Corona de Castilla en América. Pero, en cambio, es menos conocida su doctrina general acerca de la guerra, en la medida en que también juzgó la legitimidad de las guerras entre Francia y España y la del Emperador y el Papa contra el infiel ${ }^{60}$. Vitoria se interesa por desarrollar una teoría de la guerra justa que, en realidad, constituye una reelaboración de las ideas agustinianas y tomistas al respecto, aunque ahora enunciadas a la luz de las nuevas circunstancias históricas.

Defiende, siguiendo la mencionada teoría agustiniano-tomista, que los cristianos sí pueden hacer una guerra justa ${ }^{61}$ y determina cuáles son las condiciones necesarias para considerar una guerra como legítima, acudiendo para ello a la doctrina tradicional. La primera condición va a depender de la respuesta a este interrogante, apud quem sit iusta autoritas indicendi vel gerendi bellum, en quién reside la autoridad legítima para declarar o hacer la guerra. Parte de que cualquiera, incluso el simple particular, puede emprender una guerra defensiva porque es lícito repeler la fuerza con la fuerza, nam vim vi repellere licet. Pero además, cualquier república tiene autoridad para declarar y hacer la guerra, y no sólo para defenderse sino también para castigar las ofensas inferidas a ella y a los suyos ${ }^{62}$. Y asimismo, los príncipes en esta materia tienen la misma autoridad que la república, acudiendo para su argumentación una vez más a la doctrina agustiniana ${ }^{63}$.

El recurso a las armas era lícito únicamente para defenderse sólo cuando hubieran sido agotados todos los medios pacíficos y no hubiese otra forma de salvar la existencia. De ahí que rechace que la diversidad de religión sea

59. VITORIA, Francisco de, Relectio de Iure Belli o Paz dinámica. Escuela Española de la paz. Primera generación 1526-1560. Madrid, C.S.I.C., 1981. Edic. preparada por L. Pereña. V. Abril, C. Baciero, A. García y F. Maseda.

60. En De Iure Belli señala que lo importante era quitar validez a esos títulos que intentaban justificar las guerras dentro de Europa. La teoría vitoriana giraba alrededor de Milán, Borgoña y Nápoles, deseando resolver los conflictos entre Francisco I y Carlos V. Esto no significaba que Vitoria fuera enemigo de toda guerra. Contra el pacifismo erasmita y luterano defendió que la paz y la unidad de Europa sólo era posible sobre bases de justicia y libertad. De ahí que no dudara en afirmar que tanto franceses como españoles podían lícitamente vengar sus injurias por medio de las armas, cuando no hubiera otra forma posible.

61. "An omnino christianus sit licitum bella gerere" (Relectio de Iure Belli..., p. 98).

62. "Sed respublica habet auctoritatem non solum defendendi se sed etiam vindicandi se et suos" (Ibidem, pp. 116-117).

63. "Eanden auctoritatem habent quantum ad hoc principes sicut respublica. Haec expresse Agustini (contra Faustum)" (Ibidem, pp. 118). 
causa suficiente para considerar una guerra como justa, causa iusti belli non est diversitas religionis, así como tampoco la expansión territorial del imperio, non est iusta causa belli amplificato imperii, y tampoco la gloria o cualquier otra utilidad privativa del príncipe, nec etiam est iusta causa belli gloria propia aut aliud commodum principis. La única causa justa es la de la injuria recibida, una sola causa iusti belli est, scilicet iniuria accepta, aunque no basta una injuria cualquiera y de cualquier gravedad para hacer la guerra, non quaelibet et quantavis iniuria sufficit ad inferendum bellum, defendiendo Vitoria a este respecto que hay que castigar como corresponde a la gravedad de los delitos ${ }^{64}$.

La doctrina tradicional está presente ya que la posibilidad de sancionar y castigar que debe recoger el derecho es un medio de evitar las malas conductas de los hombres que, desde el pecado original, han arrastrado esa naturaleza corrupta. En la guerra justa estamos ante el mismo razonamiento, aunque a nivel superior, por el que un Estado cualquiera posee el poder coactivo para castigar al delincuente ${ }^{65}$.

No eran válidos los derechos absolutos que en abstracto permitían la guerra con otros pueblos. La moderación y la caridad, la buena fe de los príncipes, y sobre todo el bien común de la cristiandad y la amenaza turca exigían suavizar la rigidez de la justicia y castigar al enemigo con el menor daño posible a fin de que Europa no se debilitara excesivamente con peligro de su existencia y libertad. Por ello, acerca de quid et quantum liceat in bello giusto, resulta lícito hacer todo lo que sea necesario al bien público y para la defensa del bien público; recuperar las cosas perdidas o el valor compensado de las mismas; resarcirse con los bienes de los enemigos de los gastos de guerra y de todos los daños injustamente inferidos por los enemigos; también, el príncipe que hace una guerra justa puede hacer todo cuanto sea necesario para lograr de sus enemigos la paz y garantizar la seguridad; además, es lícito tomar satisfacción de la injuria recibida de los enemigos y castigarlos por esta clase de agravios ${ }^{66}$.

64. Ibidem, pp. 122-129.

65. "A diferencia de Maquiavelo, Vitoria no intenta alcanzar los principios necesarios que permitan al estado sobrevivir en medio de un mundo hostil. Tampoco anhela el retorno a la edad de oro utópica y sin discordias, de la que hablan los humanistas cristianos. Antes bien, trata de convertir la guerra -estado permanente de conflicto resultante de la interminable dialéctica de los dos órdenes seculares- en un instrumento de justicia, mediante el uso de la razón y la aplicación de la doctrina cristiana. Para Vitoria, los principios de la fe cristiana están encarnados en la doctrina de la guerra justa. Esta, que es el medio más auténtico de hacer realidad el ideal de la justicia cristiana, es el único instrumento que puede evitar que el orden internacional se vea sumido en la anarquía (...) En resumen, Vitoria no intenta separar los dos ámbitos, secular y espiritual sino que realiza un esfuerzo sutil por integrarlos" (FERNANDEZ SANTAMARIA, J.A., Op. cit., pp. 116-117).

66. Cfr. Ibidem, pp. 131-155. 
Advierte Vitoria que hay que tener en cuenta la magnitud de la injuria inferida por el enemigo, de los perjuicios causados y de los demás delitos, evitando toda crueldad e inhumanidad, oportet ergo habere rationem iniuriae ab hostibus acceptae e damni illati et aliorum delictorum. Et ex hac consideratione proceder ad vindictam omni atrocitate et inhumanitate seclusa ${ }^{67}$, así como que la guerra justa hay que emprenderla no para exterminio del pueblo contra el que se ha de luchar, sino para la recuperación del propio derecho y para la defensa de la patria, de suerte que de esa guerra resulte finalmente la paz y la seguridad, conflato iam ex iustis causis bello, oportet illud gerere non ad perniciem gentis contra quam bellandum est, sed ad consecutionem iuris sui et defensionem patriae, ut ex illo bello pax aliquando et securitas consequatur $^{68}$. Es así como en De Iure Belli y en la Questio 40 de Bello vitorianas se sientan las bases de un cuidado proceso de reflexión académica sobre la violencia y la guerra legítima ${ }^{69}$.

Los interrogantes vitorianos del XVI nos resultan ciertamente familiares. Lo que puede o no permitirse en una guerra justa no es un tema ya concluido sino que se sigue debatiendo en la actualidad. Las dudas vitorianas y sus

66. Cfr. Ibidem., pp. 131-155.

Cuestiones más controvertidas son las de si basta, para que una guerra sea justa, que el príncipe crea tener la justicia de su lado; la de si están obligados los súbditos a examinar las causas o pueden luchar sin preocuparse de ellas; la de qué se debe hacer cuando las justas causas de la guerra son dudosas y existen razones aparentes y probables en favor de una y otra parte; la de si puede ser justa una guerra para ambas partes o la de si el que, bien sea el príncipe o el súbdito, ha tomado parte por ignorancia en una guerra injusta deba restituir después si le consta la injusticia de esa guerra (Cfr. Ibidem, pp. 156-161).

67. Ibidem, p. 182.

68. Ibidem, p. 204.

Vitoria, en su Quaestio de Bello (En: "Relectio de Iure Belli...") realiza un examen exhaustivo de las diversas y variadas cuestiones que puedan presentarse en la guerra tales como la de si es siempre pecado hacer la guerra, utrum bellare semper sit peccatum, o la de si es lícito usar de asechanzas en la guerra, utrum sit licitum in bellis uti insidiis (p. 210 y p. 257).

69. No nos detenemos en el estudio de la sedición, a pesar de su proximidad al tema de la guerra y de que en los trabajos vitorianos aparezca una amplia referencia a la misma, como demuestra su Questio de seditione. En ésta destaca que la sedición por una parte coincide con la guerra y con la reyerta y, por otra, se diferencia de ellas. Coincide en la medida en que implica una cierta confrontación: se da, lo mismo que en ellas, una agresión y una defensa; de lo contrario no habría guerra o reyerta. También se habla de sedición cuando hay un agresor y un defensor.

La sedición, por otra parte, se diferencia de la guerra y de la reyerta en dos cosas. Primero, en que la guerra y la reyerta implican mutuo enfrentamiento en un conflicto actual. En cambio, puede hablarse de sedición bien cuando el enfrentamiento esté ya desarrollándose o cuando se trate de una preparación para tal enfrentamiento. La segunda diferencia es que la guerra se hace propiamente contra extranjeros y enemigos, como de nación a nación; la reyerta, en cambio, se da entre pocos, es decir, de uno a otro o de pocos a pocos; y la sedición se da entre muchos. Por ello, la sedición propiamente se da entre partidos de un mismo colectivo que están en discordia entre sí. De ahí que el bien al que se opone la sedición sea especial: el de la unidad y la paz en la comunidad (Cfr. Questio de seditione. En "Relectio de Iure Belli...", pp. 264-267). 
"rudimentarias" soluciones acerca de lo permitido en una guerra legítima han servido de base al Derecho internacional y a los diferentes convenios para elaborar las directrices oportunas acerca de los conflictos bélicos. Su postura, en el tema de quantum liceat in bello iusto, era la de condenar la destrucción de las ciudades y la muerte en masa de los culpables así como el derecho de conquista; la de limitar el derecho de ocupación y requisa de bienes y la de defender el derecho de los prisioneros a su vida y la inviolabilidad de los rehenes ${ }^{70}$, principios bastante semejantes a los que en la actualidad adopta la Iglesia católica, como veremos más adelante.

Los autores de la Escuela de Salamanca ${ }^{71}$, de los que Francisco de Vitoria constituye su representante más emblemático, -la "Escuela de la paz"han recibido algunas críticas que les acusaban de haber dado excesivo realce

70. Recurriendo Vitoria al Antiguo Testamento considera que no es lícito matar a los niños ni a los inocentes aunque sí admite que pueda reducírseles a cautividad, eodom modo licet ducere illos in captivitatem, sicut licet spoiale illos, quia libertas et captivitas inter bona fortunae reputantur (Op. cit., p. 176). Admite, siguiendo la doctrina agustiniana que, si los enemigos se niegan a restituir los bienes arrebatados injustamente y el perjudicado no pudiera resarcirse buenanente de otro modo, puede tomar satisfacción de donde sea, tanto a costa de los culpables como de los inocentes, si hostes nolunt restituere res iniuria ablatas et non possit qui laesus est, aliunde commode recuperare, potest undecumque satisfactionem capere sive a nocentibus sive ab innocentibus (Op cit., p. 174).

71. También los miembros de la segunda generación de la Escuela salmantina contribuyeron con sus aportaciones al desarrollo de la teoría de la guerra justa, destacando entre ellos Juan de la Peña. Fue célebre su Tractatus de Bello contra insulanos y, especialmente sus comentarios acerca de la Quaestio 40 de bello (Vid. De Bello contra insulanos. Intervención de España en América. Escuela Española de la paz. Segunda Generación 1560-1585. Ed. preparada por L. Pereña, V. Abril, C. Baciero, A. García, J. Barrientos y F. Mased. Madrid, C.S.I.C., 1982).

En esta última Quaestio 40, siguiendo el modelo vitoriano acerca de las guerras de conquista, denota una profunda preocupación por la paz. Defiende que el imperio del derecho debe dominar sobre la razón de Estado. El "Estado-víctima" debe adquirir jurisdicción sobre el culpable y la fuerza convertirse en un medio de paz. Su interés se centra en describir una serie de recursos pacíficos que el Estado, víctima de la agresión, debe agotar antes de recurrir al uso de las armas (Cfr. Op. cit., p. 69).

Las doctrinas agustinianas y tomistas denotan también su clara influencia en el pensamiento de Juan de la Peña. Es muy frecuente en su comentario a la Questio 40, las reiteradas citas, además de las ya citadas, las de los comentarios escriturísticos de Alfonso de Madrigal, más conocido como el Abulense o el Tostado.

En mi estudio acerca del pensamiento tostadista (Política y humanismo en el siglo XV. El maestro Alfonso de Madrigal, el Tostado. Universidad de Valladolid, 1987), destaco que su concepción del derecho de la guerra gira en torno a la paz y a la justicia. La guerra como tal no tiene sentido; sólo está justificada si cumple ciertas condiciones con el fin de que se establezca la paz y brille la justicia. Reclama Alfonso de Madrigal, la existencia de "causa manifiesta de ofensa" para que pueda ser lícito hacer la guerra, "fazer obras de enemygo". Tal causa puede girar en torno a determinadas injurias recibidas. Y es preciso que además de justa causa, sea la pública autoridad quien declare el comienzo de las hostilidades, auctoritate publica debet hoc (bellum indicere) fieri (Op. cit., pp. 160-168). (Vid. también PEREÑA VICENTE, Luciano, El sistema de 'El Tostado' en el Derecho de gentes. Madrid, 1956). 
a la licitud de la guerra justa frente a otros humanistas de su tiempo como Erasmo $^{72}$ o Vives ${ }^{73}$ que, por el contrario, eran partidarios del pacifismo. Asimismo, se les critica que su doctrina sirviese de cobertura ideológica para justificar guerras de religión (bien fueran contra los turcos o para oponerse al movimiento protestante o para la conquista del Nuevo Mundo). Se cuestionaba si este empeño en justificar la guerra -la guerra justa- no era contrario a las ideas cristianas que debían defender.

Conviene tener presente que los teólogos-juristas de la Escuela salmantina insistieron en la ponderación de las causas y procedimientos lícitos al valorar la justicia y la validez jurídica de la guerra. Además de la auctoritas legítima y de la iusta causa, el bellum iustum exigía una continua revalidación de la recta intentio que debía de estar presente en todo el desarrollo de

72. Las ideas de Erasmo sobre la guerra, que el humanista desarrolla en los primeros tratados que escribió, constituyen, a juicio de Fernández Santamaría, un claro rechazo de los principios básicos de la teoría de la guerra justa. Argumentaba que los cristianos no podían hacer la guerra porque las enseñanzas de Cristo se oponían a este comportamiento; que los derechos de los príncipes eran cuestionables; que era un mito considerar que la guerra se hacía para defender al más débil porque normalmente el inocente era el que más sufría, etc.

Sin embargo, estas consideraciones no desembocan en un abismo insuperable entre Erasmo y los defensores de la guerra justa, a juicio de Fernández Santamaría. Por una parte, porque la posición neoescolástica no es dogmática y todos los peligros que para Erasmo conlleva la teoría de la guerra justa (y que parecían llevar a la conclusión de que se trataba de un pacifista) son contemplados por Vitoria, descubriéndose una flexibilización en la posición vitoriana tradicional hacia la guerra. Por otra parte, en los últimos años de Erasmo, sus escritos traslucen una posición menos intransigente hacia la guerra. De ahí que entre la nueva postura de Erasmo y la flexibilidad vitoriana, se pueda llegar a admitir la posibilidad de un acercamiento entre los dos pensadores (Cfr. Op. cit., p. 147).

73. Una de las ideas centrales del pensamiento de Luis Vives, según el parecer de Fernández Santamaría, era que la concordia constituía el único remedio para los males del mundo y que era el hombre, y no el estado, o un príncipe, quienes conseguirían llevar una paz verdadera al mundo. La concordia es la que provocó que los hombres se asociaran: permitió fundar y preservar ciudades; introdujo los oficios, la tranquilidad, el crecimiento en virtud y sabiduría, etc. En cambio, la discordia representa todos los factores que aislan al hombre de los otros hombres. Llevó a sospechar a unos hombres de otros, destruyó las ciudades, provocó la pereza y la inmoralidad. Se interrogaba Vives por qué estába la humanidad enzarzada en una incesante guerra y concluía que la causa de todos los males había que buscarla en la ambición del hombre (Cfr. $O p$ cit., pp. 148-150).

De ahí que, por ejemplo, Vives responda al argumento de que la recuperación de la propiedad que ha sido robada injustamente a su propietario legítimo es una razón de peso para declarar una guerra justa, afirmando que se utiliza muchas veces para ocultar la ambición. Considera en definitiva, que es mucho mejor para el hombre perdonar que perseguir la amarga satisfacción de la venganza o de la represalia justa. Asimismo, frente al argumento que sostenían con más fuerza los defensores de la doctrina de la guerra justa como el que en determinadas condiciones la seguridad del estado y de la sociedad sólo pueden preservarse declarando la guerra al enemigo que busca la destrucción de la comunidad es también rechazada, porque considera que el rey que está enzarzado en la guerra no controla su reino ni puede mantener la ley y la equidad (Cfr. Ibidem, pp. 150-153). 
la guerra. Esta recta intentio desaparecía si el propósito de la paz faltaba. De ahí que, entre las diversas causas de guerra justa que pudieran enumerar, aparece en el fondo, como elemento aglutinador, la paz ${ }^{74}$. Además, no consideraban justa la guerra ofensiva de conquista sino sólo la defensiva y ésta sometida a las condiciones que acabamos de exponer. Ciertamente, Vitoria tiene gran cuidado en exponer las causas que justifican la guerra, casi con precisión escolástica. Pero ¿acaso no existieron guerras que quedaban justificadas por ambos bandos? ¿Se puede, con la doctrina vitoriana, distinguir claramente las guerras justas de las injustas?

Lo que quizá no llegaron a expresar bien estos autores fue la condición primariamente jurídica de la licitud de la guerra, prestando excesiva atención a los aspectos éticos y de conciencia. Continuaron ocupándose de la guerra a propósito del tema moral de las acciones caritativas del hombre, como había hecho Santo Tomás ${ }^{75}$, interesándose más por lo que la guerra pudiera significar para el cristiano y la teología que para el Derecho internacional. Como ya hemos indicado, si para San Agustín la paz era ordinata concordia, los autores de la Escuela salmantina pusieron el acento más en la perspectiva de la concordia que en la del orden jurídico ${ }^{76}$.

La lectura y el estudio directo de estos autores disipa algunas de las objeciones enunciadas porque su conocimiento, en la mayoría de las ocasiones, había sido indirecto a través de la divulgación neoescolástica católica ${ }^{77}$. Por otro lado, no puede negarse la honda huella que dejaron en la legislación y en el gobierno del Nuevo Mundo así como en la obra evangelizadora que allí se llevó a cabo ${ }^{78}$.

IV. La evolución del siglo XVI al siglo XVIII condujo a la cristalización de un concepto de guerra más humanizado. Baltasar de Ayala ${ }^{79}$ da el paso decisivo con respecto a Vitoria y a toda la Edad media al considerar que sólo la

74. SORIANO, Ramón, Op. cit., p. 140 (en nota 3).

75. En la Summa Theologiae, la guerra aparece tratada en la parte dedicada a la caridad (2-2 q.40), y no en el tratado del derecho y la justicia (2-2 q.57). Santo Tomás había situado su doctrina acerca de la guerra más en el ámbito moral que en el del derecho.

La aportación de Vitoria y los demás teólogos-juristas que siguieron el cauce por éste iniciado se dirige a lograr una secularización de la guerra y una aproximación al terreno jurídico a la vez que, aun siguiendo la doctrina tradicional, reclama un alcance universal.

76. Ibidem.

77. Cfr. OSUNA FERNANDEZ-LARGO, Antonio, Op. cit., p. 205.

78. Cfr. BRUFAU PRATS, Jaime, La conquista del Nuevo Mundo a la luz de la doctrina de la escuela salmantina sobre la guerra justa. En: “A.F.D.”. T. VIII (1991) p. 36.

79. Fue auditor del ejército español en los Países Bajos insurrectos y publicó en 1582 sus tres libros De jure et officiis bellicis et disciplina militari (SCHMITT, Carl, Der Nomos der erde in völlkerrecht des jus publicum europaeum. Berlín, 1974. Citamos por: El Nomos de la tierra en el Derecho de gentes del Ius Publicum Europaeum. Madrid, Centro de Estudios Constitucionales, 1979, p. 174). 
lucha armada entre soberanos estatales es guerra en el sentido del Derecho de Gentes y puede corresponder al concepto de ius hostis. Todo lo demás es persecución penal y supresión de bandidos o rebeldes. La cuestión del bellum iustum es distinguida de la cuestión de la iusta causa belli. Iustum bellum es la guerra entre iusti hostes. En concreto, esta transformación la basa Schmitt en tres argumentos: 1) La característica de una "guerra en el sentido justo" es desviada de la justicia material de la causa justa hacia las cualidades formales de una guerra jurídico-pública, es decir, interestatal. 2) El concepto de guerra justa es formalizado por el concepto del enemigo justo; de esta forma, también el Estado soberano beligerante sin causa justa continua siendo, como Estado, un iustus hostis. 3) La decisión sobre si existe o no una causa justa le corresponde exclusivamente a cada soberano estatal.

C. Smichtt advierte que la teoría medieval de la guerra justa había llegado a ser problemática como consecuencia de un exceso de claúsulas y distinciones para su aplicación práctica (como lo habían expresado las numerosas dudas de Vitoria al respecto) que hacían preguntarse cuál de entre todas las guerras de la historia de la humanidad había podido ser verdaderamente justa desde el principio al fin. El postulado de la causa justa era sometido a revisión por los argumentos escépticos, agnósticos... Cabía incluso admitir la posibilidad de que ninguna de las partes beligerantes estuviera en su derecho cuando había hecho la guerra. También podía darse que una guerra que al principio era justa en uno de los lados se convirtiera, por ejemplo por represalias totalmente desproporcionadas en el curso de los acontecimientos, en una guerra justa para el bando contrario. ¿Cuál sería entonces la situación ante una guerra parcialmente justa? ¿Como contestar a las innumerables y complicadas preguntas acerca de los hechos y la culpabilidad cuando se tratara de guerras de coalición y en una época de política secreta de gabinete? ${ }^{80}$.

1) Con Niccolò Machiavelli se abandona el cuestionarse acerca de "cómo deban ser" las guerras para limitarse a las guerras tal "como son"; se produce un cambio de perspectiva mediante el que se abandona el reino del deber ser para pasar al reino del ser ${ }^{81}$. Maquiavelo se propone separar el problema del ser de la política del problema moral que supone la política. Propone pasar de una concepción normativa de la política a una concepción descriptiva de la misma: se produce así una ruptura con la tradición cristiano-medieval. La inspiración naturalista con que Maquiavelo reviste la política implica la separación entre política y ética ${ }^{82}$. La política, al independizarse

80. Cfr. Ibidem, pp. 177-180.

A estas cuestionès habría que añadir la derivada del problema decisionista que el concepto de la soberanía hace surgir necesariamente desde Bodino: ¿quién es el que decidirá? ¿quién es en realidad competente para decidir en las cuestiones y problemas jurídicos a los que conduce la investigación de la causa justa? (Cfr. Ibidem).

81. Cfr. CALSAMIGLIA, Albert, Op. cit., p. 30.

82. Esta disyuntiva contribuye a entender los planteamientos de la llamada "razón de estado". "Ante la imposibilidad de negar razonablemente el hecho de que los estados obraban 
de la ética se convierte en una técnica de adquisición, conservación e incremento del poder en el Estado y ya no habrá que enjuiciarla desde el punto de vista trascendente de una regla moral superior sino desde el punto de vista de la adecuación de los medios al fin ${ }^{83}$. Il principe de Maquiavelo es una persona pública antes que privada y la ética queda relegada a esa esfera privada del príncipe. En esta perspectiva habría que entender la afirmación de Weber de que "quien hace política pacta con los poderes diabólicos que acechan en torno de todo poder (..) quien busca la salvación de su alma y la

con frecuencia maquiavélicamente, se recurrió a una solución de urgencia que ha gozado de gran fortuna hasta nuestros días: la razón de estado (...) La teoría de la razón de estado significa ante todo la confesión y la admisión de este dualismo entre ética y política, la imposibilidad de conjuntar en determinadas circunstancias las exigencias de la política con las normas de la moral; en segundo lugar, significa también un nuevo intento de solucionar el problema de las relaciones entre ética y política. (...) La guerra y todas sus tristes secuelas, la desigualdad de clases, la substracción al individuo de sus bienes por el bien del estado, la tortura, la persecución y eliminación de grupos étnicos diferentes se tenían por medios justos y honestos cuando no el particular sino el estado, su interés común, lo demandaban”. Considera E. García Estébanez que ni el mismo Santo Tomás, con su doctrina de la superioridad del bien común sobre el particular en virtud del principio del todo y la parte, logra sortear este dualismo (El bien común y la moral política. Barcelona, Herder, 1970, p. 105 y pp. 121-122).

Sobre la razón de estado, Fernández Santamaría diferencia la postura de los eticistas de la de los realistas: "mientras los eticistas machaconamente insisten en subordinar la política a una ética de orientación religiosa, los realistas calladamente encaminan sus esfuerzos hacia lo que la realidad política exige. Los primeros elaboran su "cristiana razón de Estado" -aquellos, al menos que no llegan al extremo de condenar a la razón de Estado en términos absolutos- en base a una ofensiva sin piedad contra Maquiavelo y el maquiavelismo. Los segundos, por el contrario, dejan que el tema del maquiavelismo pase discretamente a un segundo plano, y tanto la frase "razón de Estado" como las definiciones explícitas de su significado sufren un eclipse parcial, a favor de unas formulaciones más sutiles y proporcionadas a la creciente sofisticación de los puntos de vista del realismo" (Razón de Estado y política en el pensamiento español del Barroco (1595-1640). Madrid, Centro de Estudios Constitucionales, 1986, p. 15).

83. "La razón de estado pudo en definitiva ser cosa, más que de hacer, de pensar, de esta forma de hacer que es el pensar (...) Una cierta política pudo efectivamente originarse por entonces: reglas de poder con una cierta ignorancia de cánones religiosos y normas jurídicas; (...) No sólo se trataba por supuesto de poder matar, sino también de poderse hacer otras cosas que sirvieran para potenciar un Estado, como procurarse recursos al margen de usos y acuerdos de unos estados" (CLAVERO, Bartolomé, Razón de Estado, razón de individuo, razón de historia. Madrid, Centro de Estudios Constitucionales, 1991, p. 29).

Esta razón de estado contó también con detractores. Así por ejemplo, Tommaso Campanella, en su obra más conocida, intentó mostrar los caminos prácticos que permitían escapar al egoismo de la razón de estado y que habían de conducir a la solidaridad social de la "Ciudad del sol". Sin embargo, el hecho de combatir el maquiavelismo le condujo a insertarlo en su pensamiento y en su obra de modo que, a juicio de Friedrich Meinecke, la razón de estado, combatida unas veces y manejada otras, se convirtió en el centro motor de su política (Cfr. La idea de la razón de Estado. Trad. de F. González Vicén. Reimpresión. Madrid, Centro de Estudios Constitucionales, 1983 , p. 100 y p. 105).

Esta opinión es también sustentada por Manuel Fernández de Escalante (Cfr. Libertad natural y poder político en el Estado perfecto de Tomás Campanella. Universidad de Sevilla, 1969; también, Cfr. El Derecho natural entre la "exigencia" ética y el "razonamiento" político. 
de los demás que no la busque por el camino de la política, cuyas tareas que son muy otras, sólo pueden ser cumplidas mediante la fuerza. El genio o el demonio de la política vive en tensión interna con el dios del alma" 84 .

Esta autonomía de la política con respecto a la ética por parte de Maquiavelo ${ }^{85}$ se reconoce facilmente en sus ya conocidas máximas acerca de cómo deba comportarse el príncipe ${ }^{86}$. Pero la política de Maquiavelo no sólo es amoral sino que no tiene límites jurídicos, como se deduce de las dos maneras de combatir que diferencia: una según el derecho, la otra con la fuerza: la primera es propia del hombre y la segunda de las bestias pero como en ocasiones la primera no basta, conviene recurrir a la segunda ${ }^{87}$. De ahí que el derecho sea un instrumento en manos del príncipe, preocupado por incrementar y afianzar el poder del Estado, utilizando como instrumento para su consecución, la política, a la que consideraba como el arte de detener a los hombres en la pendiente de la corrupción ${ }^{88}$. No hay aquí rastro, como tampoco encontraremos en Hobbes siglo y medio más tarde, de la concep-

En: "Actas del Congreso del Derecho Natural Hispánico" (1974) p. 87, nota 9. Sobre la razón de estado, vid. Alamos de Barrientos y la teoría de la razón de estado en España. Barcelona, Fontmara, 1975). En este contexto, resultan sumamente sugerentes las ideas expresadas por Fernández de Escalante (vid. Concentración del poder y voluntarismo en la implantación del Estado moderno. En: "Anales de la Universidad Hispalense". Sevilla (1966) Serie roja, pp. 168241), especialmente las que tienen como base los aforismos políticos de T. Campanella y el concepto de "virtú" acuñado por Maquiavelo.

84. Op. cit., pp. 173-174.

85. A este respecto señala J.A. Fernández Santamaría que: "Maquiavelo se ve aquejado, como consecuencia de su misma astucia como observador, por una deficiencia igualmente importante: la estrechez de miras. Esto le lleva a olvidar algunos imperativos tradicionales de la época. Más específicamente, no comprende que aunque la visión tradicional cristiana no satisfacía todas las condiciones indispensables a la nueva época, seguía siendo un factor lo bastante influyente todavía como para impedir el éxito de una justificación doctrinal de la sociedad, el estado, y la guerra en términos puramente seculares" (El Estado, la guerra y la paz. Op. cit., p. 121).

86. "Debbe, per tanto, uno pincipe non si curare della infamia di crudele, per tenere li sudditi suoi uniti e in fede; perchè, con pochissimi esempli, sarà più pietoso che quelli e' quali, per troppa pietà, lasciono seguire e' disordini, di che ne nasca occisioni o rapine; (...) è molto più sicuro essere temuto che amato, quando si abbia a mancare dell'uno de' dua. Ma quando il principe è con gli eserciti e ha in governo moltitudine di soldati, allora al tutto è necessario non si curare del nome del crudele, (...) Sendo, dunque, uno principe necessitato sapere bene usare la bestia, debbe di quelle pigliare la golpe e il lione” (Il Principe. cap. 17. En: “Op. cit.”, pp. 281-283).

87. "Dovete, adunque, sapere come sono dua generazioni di combattere: l'uno con le leggi, l'altro con la forza: quel primo è propio dello uomo, quel secondo è delle bestie: ma perchè el primo molte volte non basta, conviene ricorrere al secondo" (Ibidem, cap. 18. En: "Op. cit.", p. 283).

88. Señala Manuel Fernández de Escalante que "en la concepción maquiavélica "el Estado", como fortísima acumulación de poder anuladora de poderes intermedios, surge pues (...) a manera de "antídoto fuerte" contra la "anarquía", como contraveneno contra la corrupción" (De Maquiavelo a Hobbes: una nueva configuración de la vida social. En: "Verbo" 3 (1972) p. 979). 
ción cristiana tradicional de una ley ética natural por la que el hombre participe de un orden superior divino.

Por todo ello es evidente que para Maquiavelo la guerra juega un papel fundamental para lograr el objetivo que se propone el gobernante (el de conservar e incrementar su poder), hasta tal punto que la llega a caracterizar de arte, l'arte della guerra ${ }^{89}$. Esto era consecuencia de considerar la situación internacional, entre príncipes, como una situación de guerra contra todos y de ahí que entendiera que la única forma de sobrevivir fuera haciendo preparativos para la guerra ${ }^{90}$.

2) Será Hugo Grocio el que intente sentar las bases del Derecho internacional defendiendo que el derecho debe prevalecer no sólo sobre los intereses particulares de los individuos sino también de los Estados. El derecho dentro de las relaciones internacionales tenía un enemigo que era el maquiavelismo reinante en la política exterior de los Estados, donde la razón y el interés de los Estados, dejando de lado cualquier connotación religiosa o moral, quería imponerse. En De Iure Belli ac pacis Grocio quiere ofrecer una teoría del derecho de la guerra y de la paz. El crecimiento de los Estados nacionales había resquebrajado los cimientos de la res publica christiana. El Papa y el Emperador ya no tendrán ese dominium mundi. De ahí que Grocio sienta la necesidad de crear un orden nuevo, basado en una justicia universal, nacida de la misma naturaleza del hombre ${ }^{91}$.

Considera Grocio que dirimir una contienda por medio de la fuerza es un medio ordinario que utilizan para resolver una controversia los que todavía no han aceptado un Derecho civil común de los pueblos, el Derecho de gentes, como son los que no se han constituído todavía en pueblo, o los que son de distintos pueblos o tienen una autoridad semejante a la de los príncipes. Defiende pues, que existe un derecho tanto en tiempo de guerra como en tiempo de paz y que éste es el medio más eficaz para resolver las posibles controversias $^{92}$. Señala la equivocación de aquellos que piensan que todo derecho cesa ante la guerra: al contrario, considera que no debe emprender-

89. Esto lo demuestra su obra Dell'arte della guerra, en la que considera satisfactorio ser llamado a las milicias y tener así ocasión de servir a su príncipe : "Però si debbe prendere una via di mezzo dove non sia né tutta forza nè tutta volontà, ma sieno tirati da uno rispetto ch'egli abbiano al principe, dove essi temano più lo sdegno di quello, che la presente pena" (lib. I. En: “Op. cit.", p.311).

90. Destaca en Il Principe: "Filipomene, principe degli Achei, intra le altre laude che dagli scrittori gli sono date, è che ne' tempi della pace non pensava mai se non a' modi della guerra" (cap. 14. En: "Op. cit.”, p. 279)

91. Cfr. Hugo Grocio. Del derecho de presa. Del derecho de la guerra y de la paz. Textos de las obras "De Iure Praedae" y "De Iure Belli ac Pacis". Ed. bilingüe. Trad., introd., y notas de Primitivo Mariño Gómez. Madrid, Centro de Estudios Constitucionales, 1987, p. XIX.

92. Cfr. De Iure Belli ac Pacis, lib. I, cap. I. En: "Op. cit.", p. 53.

Considera Grocio que, etimológicamente, la guerra procede del antiguo duellum, como de duonus procede bonus, y duis, que significa dos, da origen a bis. Duelo se dice de dos, en el mismo sentido que denominamos paz a la unión (Ibidem). 
se la guerra sino para conseguir el derecho y que, una vez iniciada ésta, debe llevarse a cabo según la forma de derecho y de buena $\mathrm{fe}^{93}$.

Arrancando de la doctrina de la guerra justa de la Escuela salmantina, inicia Grocio un proceso doctrinal que, especialmente a través de Vattel, configura la guerra como una institución de derecho de gentes cuya legitimidad se hará depender de una legalidad vinculada a determinadas formas. Insiste en el ius in bello, contribuyendo a configurarlo en un sentido de moderación que limita los daños no sólo mediante el principio de estricta necesidad sino también de la humanidad, de la religión y de una política a largo plazo ${ }^{94}$.

3) Tomás Hobbes mantiene una postura semejante a la de Maquiavelo con respecto a las relaciones entre los Estados ${ }^{95}$. Para Hobbes las relaciones interestatales o internacionales se encuentran todavía en un estado de naturaleza. Esto es consecuencia de que, en la naturaleza del hombre, según Hobbes, no hay ningún appetitus societatis, sino una voluntas laedendi, una voluntad de dañar que enfrenta a unos hombres con otros, en una situación de hostilidad permanente y recíproca. El hombre es un lobo para el hombre, según Hobbes: homo homini lupus est. Considera a los hombres naturalmente enemigos. El estado de naturaleza en la sociedad, la vida humana fuera de la sociedad civil es una lucha de todos contra todos. De ahí que como semejante situación de hostilidad es, a juicio de Hobbes, contraria a la conservación del género humano, los hombres acuerden hacerla desaparecer mediante el establecimiento del poder civil. Ello se realiza mediante una convención un pacto. y el resultado será el acuerdo del sometimiento al soberano a cambio de la garantía de paz y protección.

Se ha llegado a afirmar que la especie humana se encuentra en una situación hobbesiana, en la que cada gran potencia puede destruir a su antogonista y por tanto autodestruirse. Comparan el estado actual de las relacio-

93. Cfr. In tres libros de Iure Belli ac Pacis. Prolegomena. p. X. En: “Op. cit.”, p. 41.

94. C. Smichtt considera que el tema de la guerra justa en Grocio desemboca también en una "guerra en forma" entre dos iusti hostes, y en este aspecto iustus sólo expresa un requisito formal. Continúa Grocio utilizando las formulaciones tradicionales de que la guerra sólo debe ser librada ex iusta causa como si aún se encontrase en la Edad Media teológica. Se refiere a "guerras privadas" y las reconoce como guerras en el sentido del Derecho de gentes ("neque enim privatum hic excludo, ut quod re ipsa prius sit publico, haud dubie cum publico communem habeat naturam, quae propterea eoque propio nomine signanda est" (De Iure Belli ac Pacis, lib, I, cap. I, p. 2. En: "Op. cit.", p. 52). Pero al mismo tiempo afirma que no incluye la justicia en la definición del concepto de guerra ("Iustitiam in definitione non includo, quia hoc ipsum in hac disputatione quaerimus, sit ne aliquod bellum iustum, quod bellum iustum sit"(Ibidem, p. 2). (Cfr. Op. cit.; p. 187).

95. Este no es el único punto en común entre el filósofo de Malmesbury y el pensador florentino. Ambos denotan en sus escritos la necesidad de que exista un fuerte núcleo de poder 
nes internacionales, y especialmente entre las grandes potencias, con un estadio semejante al del hombre en el estado de naturaleza hobbesiano, en el que existía una radical inseguridad, no cabía presumir la buena fe y las virtudes cardinales eran la fuerza y el fraude. Por ello, "durante el tiempo en que los hombres viven sin un poder común que les obligue a todos al respeto, están en aquella condición que se llama guerra; y una guerra como de todo hombre contra todo hombre. Pues la guerra no consiste sólo en batallas, o en el acto de luchar; sino en un espacio de tiempo donde la voluntad de disputar en batalla es suficientemente conocida (...) Todo otro tiempo es paz" 96 .

Ante los inconvenientes del bellum omnium contra omnes, como hemos indicado Hobbes recomienda realizar un pacto social y lograr así la ansiada paz y seguridad ${ }^{97}$. Como señala Bobbio, cuando se habla de guerra en sentido hobbesiano se hace referencia a la valoración de la guerra como un mal absoluto y, como efecto contrario, la valoración de la paz como bien absoluto ${ }^{98}$. Esta reacción hobbesiana se entiende facilmente en la medida en que, como él mismo indicó en una ocasión, el miedo y él eran hermanos gemelos ${ }^{99}$. La época en que se desarrolló su vida fue muy insegura y de ahí ese continuo

que sea capaz de superar los poderes intermedios. Como señala Manuel Fernández de Escalante: "La idea del Estado como "monopolio de la fuerza de coacción" surge, pues, correlativamente, en dos agudos talentos, preocupados ambos ante la perspectiva del "desorden", cada uno desde sus propios "motivos": el de la "grandeza", Maquiavelo; el de la seguridad -más modestamente-Hobbes" (De Maquiavelo a Hobbes: una nueva configuración de la vida social. En: "Verbo" 3 (1972) p. 992).

96. Leviatàn. Ed. preparada por C. Moya y A. Escohotado. Trad. de A. Escohotado. Madrid, Editora Nacional,1979, pp. 224-225.

97. Señala Hobbes que al entrar a vivir en sociedad, en la "civitas", dejamos de estar protegidos por nuestras solas fuerzas y pasamos a estar protegidos por las fuerzas de todos: "Utra autem ad civium pacem conservandum, et commo eorum procuranda aptior sit, earum comparatione videndum est. Primum autem commoda et incommoda civitatis in universum conferamus, ne quis forte satius esse ducat vivere unumquenque arbitrio suo, quam civitatem omnio constituere. Extra statum civitatis, unusquisque libertatem habet integerrimam quidem, sed infructuosam" (De Cive, cap. X, 1, pp. 264-265. En: "Opera Philosophica, quae Latine scripsit omnia in unum corpus nunc primum collecta. Preparada por Gulielmi Molesworth. vol. II, $2^{\circ}$ reimpresión, Alemania, Scientia Verlag Aalen, 1966).

Y añade sobre la paz y la defensa: "Quoniam igitur conspiratio plurium voluntatum ad eundem finem non sufficit ad conservationem pacis et defensionem stabilem" (De Cive, cap. V, 6, p. 213. En: “Op. cit".).

Y también sobre el auxilio para hacer la guerra: "Prima autem et fundamentalis lex natura est, quaerendam esse pacem, ubi haberi potest; ubi non potest, quaerenda esse belli auxilia" ( $D e$ Cive, cap. II, 2, p. 170).

98. "La filosofía política a lo largo de todos los siglos de su historia no ha hecho casi nunca el uso axiológico de la antítesis guerra-paz que en cambio ha hecho Hobbes, es decir, no ha considerado nunca la guerra como un disvalor absoluto y la paz como un valor absoluto" (Op. cit., p. 170).

99. De ahí que señale Miguel Angel Rodilla que Hobbes, que como filosófo del barroco gustaba de las alegorías, personificó en Leviatán y Behemoth, los dos monstruos de la escatolo- 
deseo de paz y seguridad ${ }^{100}$. En relación a esta argumentación sobre el miedo y la política, destaca Bobbio que en Hobbes se produce una radical inversión en el juicio de valor: el miedo, de factor maléfico, se convierte en factor benéfico de la vida política. El monstruo bueno del Estado (Leviatán) nace de la recîproca necesidad que los hombres tienen de salir de esa situación de "temor recíproco" en que se encuentran en el estado de naturaleza y evitar caer en los brazos del monstruo malo de la guerra civil (Behemoth). Si no fuera por el miedo que tienen los hombres de morir unos en manos de otros en el estado de naturaleza, el Estado no habría llegado a nacer ${ }^{101}$.

El temor recíproco que induce a los individuos a salir del estado de naturaleza en las relaciones interindividuales y a instaurar un poder común supraindividual no induce sin embargo, a los Estados, a salir del estado de naturaleza en las relaciones internacionales y a instaurar un poder común supraestatal: ésta podría haber sido la solución para terminar con los posibles desórdenes internacionales ${ }^{102}$ pero, como señala Bobbio, se trata de un problema que se sale del horizonte histórico hobbesiano. Sobre las razones

gía judía, el conjunto de las condiciones del orden, por un lado, y la amenaza del desorden, por otro. Y así como en el Leviatán llevó a cabo un análisis de las condiciones de posibilidad de la paz social y la cooperación, el Behemoth constituye a su modo un estudio sobre la vulnerabilidad del orden" (Behemoth. Estudio preliminar, trad. y notas de M. A. Rodilla. Tecnos, 1992, p. $\mathrm{XII})$.

100. Cfr. PISANO, Dino "Paura reciproca" e "paura comune" in Hobbes. En: "R.I.F.D." (1975) pp. 641-691.

Resalta Pisano que para Hobbes:"Los "stato di natura" è, dunque, lo stato di guerra, lo stato contrario al fine che gli uomini si prefiggono all'atto del'istituzione dello Stato: è lo Stato in cui non c'è "decisione delle controversie", per cui non è possibile la protezione di un suddito contro le ingiurie di un altro" (Ibidem, p. 649).

101. Cfr. BOBBIO, Norberto, El equilibrio del terror. Trad. de Alfonso Ruiz Miguel. En: “A.F.D.". T.II (1985) pp. 6-7.

102. En este sentido, A. Calsamiglia considera que el artificio contractualista no sólo puede servir para el diseño de unas instituciones estatales justas sino también para el diseño de unas instituciones internacionales justas. Siguiendo este razonamiento, entiende que la construcción de un supraestado pudiera hacer posible el objetivo de la paz (Cfr. De nuevo sobre la guerra y la cooperación. En: “A.F.D.”. T.II (1985) p. 49).

Con respecto al contractualismo hobbesiano, señala que Hobbes llega a la conclusión de que el interés individual exige ponerse de acuerdo en la institución de un soberano, pero no encuentra otro medio más apropiado que el contrato. Sin embargo, no es fácil encontrar un mecanismo adecuado que resuelva el problema porque para que se cumpla el contrato es necesario que ya exista autoridad y ésta todavía no existe. En el momento en que todos los hombres deciden salir del estado de naturaleza deben entregar su fuerza y sus armas al soberano. Pero ¿cómo se puede llevar eso a cabo? ¿no sería mejor que los demás se desarmaran y permanecer armado para conseguir una ventaja sobre los demás? Considera A. Calsamiglia que la teoría contractualista de origen rawlsiano (el "velo de la ignorancia" serviría para eliminar la dificultad a la que acabamos de referirnos) puede dar lugar a una adecuada tesis del pacifismo jurídico (Cfr. Ibidem, pp. 46-47). 
por las que Hobbes considerase el temor recíproco insuficiente entre los individuos y suficiente entre los Estados, indica Bobbio que sólo se puede hacer esta conjetura: los individuos están indefensos unos respecto de otros y son tan iguales en esta imposibilidad de defensa que incluso el más débil puede matar al más fuerte (por ejemplo, cuando duerme); sin embargo, los grupos políticos una vez constituidos están en condiciones de ofrecer una defensa capaz de impedir su eliminación por parte de los demás grupos y, por consiguiente, de establecer entre sí otra forma desigualdad que no es ya la positiva, consistente en el poder de matarse entre sí, sino por el contrario la negativa, que consiste en estar en condiciones de no dejarse matar ${ }^{103}$.

Los planteamientos hobbesianos que reclaman la sumisión al soberano y la negación del derecho de resistencia es el precio que se tiene que pagar, según Hobbes, para conseguir la paz y la seguridad. Con todo, "muchos son los que han considerado que este precio es demasiado alto y que vale más una vida libre , sin paz, que una vida pacífica, sin libertad" 104.

V. En el siglo XIX la guerra parece convertirse en un hecho lógico y normal. El positivismo trajo como consecuencia que al desconocer cualquier ley superior, divina o natural, el Estado se transformara en la única fuente de derecho. Por ello, en ocasiones acaba llegándose a identificar guerra y política, aunque ésta última se llevara a cabo mediante otros medios. A su vez, los ejércitos pierden su caracter temporal y se configuran como órganos de la nación armada, robusteciéndose con motivos ideales y con armas más potentes y mortíferas.

Sin embargo, esta sociedad decimonónica es consciente del peligro que puede entrañar esta especie de culto a la violencia y, para contrarestarlo, se esfuerzan por humanizar la guerra y someterla al derecho. Así, el ius belli pasa de las obras doctrinales a las convenciones internacionales. Es el Estado de derecho, en el siglo XIX, con su principio de la supremacia de la ley el que, a juicio de Cotta, representa el punto más alto del "flujo" antiviolento ${ }^{105}$. El punto de ruptura entre el siglo XIX y el siglo XX lo señala la primera guerra mundial. Después de ésta, comienzan los ricorsi, marcados por un

103. Ibidem, pp. 7-8.

Es muy conocida la referencia al "equilibrio del terror" que realiza Bobbio como forma de evitar la guerra, aunque lamenta que el equilibrio del terror no sirva más que para eliminar la guerra nuclear. Para salir del equilibrio del terror en que se encontraba el hombre natural hobbesiano decidió renunciar al uso de la fuerza y ponerse de acuerdo con sus semejantes para constituir un poder común. Lamenta Bobbio que en la actualidad no se vea posibilidad de que el gran Leviatàn, el hombre artificial, quiera hacer lo mismo (Ibidem, p. 11 y p. 17).

104. CALSAMIGLIA, Albert, La justificación de la guerra. En: "Sistema" 52 (1983) p. 27.

105. Cfr. Perchè la violenza? Una interpretazione filosofica. L'Aquila, Japadre Editore. 1978, pp. 35-38. (Versión española: Trad. de Tomás Melendo, Las raíces de la violencia, Universidad de Navarra, Eunsa,1987, pp. 51-55). 
resurgir de la violencia, en concreto, de la violencia bélica. Se señalan sin embargo unos límites, como son la prohibición, en la práctica, de la guerra total (con cualquier medio) y global (especialmente ilimitada) ${ }^{106}$.

Esta diferencia marcada por los conflictos mundiales se deja también notar en los escritos de Giorgio del Vecchio. Si en sus primeros trabajos sigue la línea del neokantismo dominante, progresivamente y al compás de su conversión al catolicismo así como del rechazo que le provocaron los desastres y abusos de los derechos humanos con ocasión de las dos guerras mundiales, se va aproximando al pensamiento agustiniano tomista ${ }^{107}$. De ahí que sus Studi sulla guerra e la pace, que reagrupan varios de sus trabajos acerca de esta temática ${ }^{108}$, denoten asimismo ese diferente tono entre aquellos que pertenecen a su etapa de juventud y aquellos otros escritos de sus años de madurez; en estos últimos nos transmite su lamento ante la evidencia de que las máximas que había defendido con respecto a los límites de la guerra, fueran gravemente violadas con ocasión de la segunda guerra mundial.

En Il fenomeno della guerra e l'idea della pace, de 1910, parte Del Vecchio de que la existencia de una pluralidad de Estados, teniendo cada uno de ellos una personalidad y una fuerza propia de Estados, es la primera condición de la que depende la posibilidad de la guerra. Considera que ningún Estado puede evitar usar la fuerza cuando su existencia se encuentre en peligro. De ahí que una renuncia absoluta a la guerra conllevaría la negación del concepto mismo de Estado. Ello no impide a que la guerra pueda tener su origen en diversos factores históricos, psicológicos, económicos (la caza, la conquista del territorio enemigo, guerras coloniales y comerciales o por diversidad de crencias) en función de las diversas culturas pero esto no implica que deba acompañar a la historia humana en cada una de sus fases. Por el contrario, queda planteado el debate de si un desarrollo posterior en la historia deba conducir a la supresión de tal fenómeno ${ }^{109}$.

Del Vecchio en este trabajo, más que interesarse por las terribles consecuencias de la guerra se preocupa por mostrar las consecuencias specialmen-

106. Para S. Cotta esto viene demostrado por las distintas etapas por las que ha pasado la estrategia político-militar: estrategia del terror, estrategia de la disuasión y, por último, estrategia de la coexistencia (Ibidem, pp. 43-44. Las raíces de la violencia, pp. 62-63).

107. En Derecho natural y derecho positivo. El itinerario iusnaturalista de Giorgio del vecchio (Universidad de Valladolid, 1993) me ocupo de la doctrina delvecchiana destacando la evolución de su pensamiento (en su concepción antropológica, en la relación derecho-moral, en la relación entre derecho natural y derecho positivo y en la justicia).

108. Entre ellos cabe destacar su breve trabajo Le ragioni morali della nostra guerra (1915), escrito con la finalidad de animar a los soldados italianos que participaron en la primera guerra mundial. De este ensayo se distribuyeron, por orden del Comando supremo, 40.000 copias entre los combatientes y fueron traducidas en varias lenguas. En: "Studi sulla guerra e la pace". Milano, Giuffrè, 1959, pp. 73-90.

109. Cfr. Il fenomeno della guerra e l'idea della pace. En: “Op. cit.”, pp. 8-24. 
te benefiche della guerra que algunos habían resaltado. No por ello deja de reconocer que el efecto inmediato de la guera es la destrucción y la muerte. Incluso la simple preparación a la guerra (educación militar, armamento, etc.) constituye un gran gasto de energía. El gran significado de la guerra es el de que impulsa a los individuos a constituir una unidad más compleja que no es la familiar: se hace así posible l'azione del tutto ${ }^{110}$. Llega incluso a destacar que el esfuerzo para hacer eficaz la defensa y el ataque en las relaciones con otros pueblos ha constituído un poderoso estímulo para perfeccionar sus formas de actividad. De ahí que innumerables inventos y reformas técnicas fueran y todavía sean promovidas con fines guerreros ${ }^{111}$. Es consciente, sin embargo, de que si bien la guerra conlleva efectos morales positivos (come lo spirito di sacrificio e d'abnegazione), por otra parte la guerra es también un importante factor de corrupción donde las pasiones humanas se desenfrenan (desmesurados castigos a los enemigos, saqueos y venganzas injustificadas, etc. $)^{112}$.

Su interés por la guerra quedaría cercenado si no se ocupara también de la paz. De las cuatro teorías que considera que pueden explicar las concepciones teóricas de la $\mathrm{paz}^{113}$, su preferencia se dirige a la concezione giuridica, acudiendo a la doctrina rousseauniana y kantiana para su defensa. Rousseau partía de que debido a la constitución política de los Estados existentes, la abolición de la guerra era imposible. De ahí que sin sacrificar la libertad a la paz, fuera partidario de una confederación universal aunque respetando la legitimidad de las constituciones internas de los diversos Estados. Asimismo, Del Vecchio entiende que la paz perpetua kantiana, Zum ewigen Frieden, se inspira en las ideas de Rousseau y de ahí la defensa, por parte de I. Kant, del

110. Cfr. Ibidem, p. 27.

Se refiere al efecto contrario que produciría: "la minore capacità delle genti isolate e "anarchiche" a resistere contro altre politicamente organizzate e disciplinate; quindi la probabile soppressione o l'assorbimento delle prime per le seconde" (Ibidem, p. 28).

111. "in nessuna specie di attività appare più certo e quasi tangibile il continuo perfezionamiento e progresso umano, che nella guerra" (Ibidem, p. 32).

112. Cfr. Ibidem, pp. 34-35.

113. La primera es la concezione ascetica que reprueba cualquier tipo de guerra y de violencia porque son contrarias a la ley ética del amor y la fraternidad humana. Del Vecchio la rechaza porque considera que "la pace a qualunque costo" equivale en la práctica a una violencia desenfrenada.

La segunda es la concezione imperialistica o assolutistica que defiende la violencia para conseguir una absoluta dominación. Sería el modelo defendido por Dante Aligheri en su Monarchia: Il genere umano deve essere retto da un solo capo y así se consigue la pax universalis. Del Vecchio rechaza esta teoría por considerarla utópica.

La tercera es la concezione empirico-politica según la cual la paz perpetua debería obtenerse mediante diversos acuerdos o pactos entre los diversos gobiernos existentes. Considera Del Vecchio que esta concepción adolece de una superficialidad empírica de valoración porque todos los gobiernos (de cualquier forma y estructura) eran considerados en un mismo plano (Cfr. Ibidem, pp. 36-47). 
nexo inescindible entre la libertad interna de las naciones y la posibilidad de su coordinación jurídica universal. Conviene pues, alcanzar una federación de Estados libres, en los cuales la libertad y la paz se garanticen. La misma máxima que impone a los individuos renunciar a su arbitrio desenfrenado en el status naturae para entrar como súbditos de un Estado, impone a los Estados (que en sus relaciones están todavía en un status naturae) constituir a su vez una unidad política superior, una civitas gentium ${ }^{114}$.

Kant consideraba que la constitución civil de cada Estado debía ser republicana, queriendo significar lo contrario de despótica, es decir, afirmaba una constitución legítima, caracterizada por la separación de los poderes legislativo y ejecutivo y por la igual libertad de todos los ciudadanos. Sólo una constitución así podía garantizar la paz perpetua porque al corresponder a los propios ciudadanos deliberar acerca de la guerra, éstos no se verían arrastrados por aquellos motivos que son suficientes para los soberanos absolutos. Es así como se logrará esa civitas gentium cuya idea, aunque no se alcanzara de hecho, permanecería como guía en la medida en que nos aproximaramos a ella indefinidamente en el curso histórico ${ }^{115}$.

Por otra parte, Del Vecchio apunta una progresiva transformación en el caracter de la guerra, por la que ésta llega a convertirse en un procedimiento quasi-giuridico. A su juicio, el "diritto della guerra" que tiene su raíz en etapas muy anteriores, mediante las doctrinas de Vitoria y Gentile y su conexión con el derecho natural, logra que aparezca un sistema jurídico capaz de regular incluso las relaciones guerreras. Desde Rousseau queda establecido que la guerra es una relación entre Estado y Estado y para Del Vecchio la guerra participa del caracter de un procedimiento jurídico entre los Estados: la guerra ha ido adquiriendo progresivamente el caracter de medio para restablecer el derecho. De ahí que considere que no es condenable la violencia cuando tiende a reintegrar el derecho. La paz por consiguiente, prescindiendo de su referencia al derecho, es éticamente insuficiente, neutra o adiafora. Por ello, reafirma el fundamento jurídico de la paz ${ }^{116}$.

En 1956 sale a la luz Il diritto internazionale e il problema della pace, donde se manifiestan algunos cambios con respecto a trabajos anteriores sobre el mismo tema. Basándose Del Vecchio en que la guerra se manifiesta entre grupos sociales y no entre individuos (el bellum omnium contra omnes hobbesiano tiene significado como argumento dialéctico solamente) y destacando su caracter público y no privado, hace una crítica del sistema de Grocio y destaca que el mérito en el tratamiento novedoso de la guerra y del

114. Cfr. Ibidem, pp. 57-62.

Veáse al respecto El ideal de la paz perpetua en Kant (ROMERO MORENO, José Ma . En: “A.F.D.”. T.II (1985) pp. 207-216).

115. LEGAZ Y LACAMBRA, Luis, La idea y el fenómeno de la paz. En: "Derecho y paz. Op. cit.," p. 8.

116. Cfr. Ibidem, pp. 62-69. 
derecho de gentes corresponde a Alberico Gentili, sin negar el relevante papel que desempeñó, en la progresiva construcción de una guerra justa, la philosphia perennis (San Agustín, Santo Tomás y la Escuela española del XVI) ${ }^{117}$.

Se interesa principalmente por el problema de la guerra y la paz en la Edad Moderna y el papel que pueda desempeñar el Derecho internacional en esta relación. Rechaza la creencia de que cada Estado tenga un poder absolutamente arbitrario en sus relaciones con otros Estados y defiende, por el contrario, el deber de reconocer los pactos y tratados internacionales voluntariamente acordados entre los Estados. Se hace necesaria la limitación jurídica de los medios bélicos (armas atómicas, etc.) por las graves consecuencias que podría producir su utilización. El objetivio debe ser la abolición total y definitiva de la guerra y la única vía que Del Vecchio ve factible para hacer realidad ese objetivo es la creación de órganos capaces de resolver los conflictos interestatales de forma jurídica ${ }^{118}$.

El problema surge, a su juicio, como consecuencia de que el género humano está dividido en grupos políticamente organizados y las relaciones entre los mismos no están reguladas por una ley universalmente aceptada. Los factores que han convertido en vanos los múltiples esfuerzos pueden reducirse a tres principalmente: una imperfecta concepción del derecho, el desconocimiento de la ley natural y la teoría de la ilimitada soberanía de los Estados. La aproximación del pensamiento delvechiano a la doctrina cristiana le lleva a afirmar que el establecimiento de la paz duradera tiene como condición el reconocimiento de un vinculo spirituale entre los hombres que implica l'obbligo del rispetto reciproco ${ }^{119}$.

Considera que los Estados deben aceptar un orden supranacional. Al igual que un Estado es legítimo en la medida en que respeta los derechos naturales de'las personas que lo integran, no puede, por consiguiente, sentirse disminuido si el mismo principio se aplica a sus relaciones con otros Estados. Del Vecchio admite una sola causa para aceptar el recurso a la guerra: la necesidad de tutelar un derecho amenazado o lesionado que no pueda tutelarse de otro modo. Considera absurdo negar a un Estado la facultad de resistir a una agresión ${ }^{120}$. El "non resistere al male" personal puede hacerse

117. Cfr. Ibidem, pp. 143-170.

118. Cfr. Ibidem, pp. 171-179.

Recurre, en ésta su etapa de madurez, a la tradición de la philosophia perennis como aquella que ofrece las claves idóneas para resolver las dificultades acerca de la guerra y la paz (Ibidem, p. 179).

119. Cfr. Ibidem, pp. 182-184.

"Verità semplice, che invano si è voluta impugnare o diminuire con erronea argomentazio$\mathrm{ni}$, ad esempio dando ad essa un significato meramente religioso o morale, e non anche giuridico" (Ibidem, p. 184).

120. "Ma fuori del caso di una immediata necessità di difesa, varie considerazioni ci inducono a non ammetere la licità della guerra" (Ibidem, p. 186). 
pero no cuando se trata del mal que se hace a otros y tenemos la posibilidad de impedir ${ }^{121}$. Recuerda la observación de A. Ottaviani al respecto, acerca de que los Estados más audaces y más inicuos podrían impunemente agredir cuando no temieran la fuerza contra la violencia y habría acabado así la justicia entre los pueblos si un pacifismo siempre pasivo permitiera que quedaran impunes las agresiones ${ }^{122}$.

Las características con que reviste a la guerra son las de que se trata de un verdadero derecho fundado en la ley natural y no de un mero interés; debe darse además en aquellos casos en que se trate de defender un derecho esencial a la vida ( y no de una aspiración, aunque sea legítima, o de cualquier tipo de ventaja). Y, por último, a la extrema ratio de la guerra sólo es lícito acudir después de haber agotado todos los medios posibles para llegar a una solución del conflicto, porque en definitiva, la guerra no puede ofrecer nunca la garantía de conducir a una paz justa ${ }^{123}$.

Si en un principio, como hemos visto, Del Vecchio defendía que la guerra podía tener el caracter de un procedimiento giurico o "quasi giuridico", los hechos acaecidos con motivo de la segunda guerra mundial le demostraron que esto no se cumplía ${ }^{124}$. De ahí que defendiera que la renuncia a la guerra no puede ser absoluta. Además, la licitud de la guerra reclama que no sólo deba ser contenida en los estrictos límites sino excluida salvo en los casos extremos de legítima defensa frente a una agresión o en una legítima reacción contra una intolerable violación de los más elementales derechos humanos ${ }^{125}$. Por ello Del Vecchio, frente a G. Radbruch quien consideraba imposible distinguir la guerra justa de la injusta, defienda que, aunque en ocasiones sea difícil, en la medida de lo posible se puede y debe valorar y diferenciar lo justo y lo injusto ${ }^{126}$.

La postura delvecchiana defensora de la existencia del derecho internacional como verdadero derecho (puesto que defendía la existencia de una

121. Cfr. Ibidem, pp. 129-139.

Se basa en la doctrina cristiana para ratificar esta afirmación: "L'ingiustizia, secondo la dottrina cristiana, deve essere combattuta, e non accettata supinamente" (Ibidem, p. 129).

122. Ibidem, p. 139 (en cita 2).

123. Cfr. Ibidem, pp. 186-187.

124. Entre las condiciones que integraban ese principio se encontraban las de que "i non combattenti dovessero essere risparmiati, e che anche tra i combattenti dovessero essere escluse certe specie di offese particolarmente crudeli" (Ibidem, p. 188).

125. Cfr. Ibidem.

126. "Concediamo pure che in qualche caso la ragione ed il torto possano stimarsi divisi in egual misura tra le due parti; ma dove la sproporzione delle forze sia manifiesta e grandissima, dove manchi non solo la prova, ma anche la possibilità di una qualsiasi minaccia da parte dello Stato più debole, dove non sussistano nemmeno antichi torti da riparare, non vediamo perchè la nostra mente dovrebbe arrestarsi e astenersi in questa materia da quella valutazione del giusto o dell'ingiusto, che scaturisce, come insegnava Aristotele, dalla stessa nostra natura, e che s'applica a qualsiasi manifestazione di volontà" (G. Radbruch e la guerra. Appendice. En: "Op. cit.", p. 226). 
verdadera comunidad o sociedad internacional, de forma que el "Derecho de gentes" regía, no sólo en virtud de pactos o convenciones, sino en cuanto impuesto a los Estados" particulares por la "autoridad de todo el orbe") presentaba sin embargo una clara dificultad. Ciertamente, tal comunidad puede afirmarse que "moralmente" existe, que es posible y deseable e, incluso, que parcial e imperfectamente actúa como tal, pero no puede afirmarse que exista como tal entidad jurídico-política determinada de forma que pueda implantar una normativa como propia e imponerla obligatoriamente a los Estados particulares considerados como sus miembros ${ }^{127}$.

Ligado a esta deficiente validez jurídica del derecho internacional se encuentra su también deficiente pretensión de eficacia, lo que se manifiesta, entre otras cosas, en la ausencia de una auténtica imposición coactiva del mismo. Esta deficiencia es palpable: baste observar como se impone el derecho interno de cada Estado y la dificultad, por parte del derecho internacional, para imponer un orden en la vida social. De ahí lo que ocurre en el derecho de la guerra, esa pretensión límite del derecho por someter a un orden las pugnas sociales ${ }^{128}$.

De ahí también que algunos filósofos del derecho, como por ejemplo Hans Kelsen, pongan de relieve la inferior capacidad del derecho internacional frente al derecho interno de cada Estado, en aras de la consecución de la paz social, ya que aquél, a su juicio, no goza de una plena imposición coactiva. Para Kelsen, la paz consiste en la ausencia de fuerza: en el orden estatal interno esto se consigue evitando el empleo arbitrario de la fuerza en las relaciones sociales y reservando su uso de manera exclusiva a la comunidad a través de sus órganos, garantizándose así un monopolio en el uso de la fuerza. Es esto lo que falta en el ámbito del derecho internacional. De ahí que Kelsen considere imposible que el derecho internacional se convierta en derecho interno a estos efectos ${ }^{129}$.

Sin embargo, para mejorar la eficacia de aquél, considera Kelsen ${ }^{130}$ que la solución podría encontrase en la creación de un Tribunal Internacional al

127. DELGADO PINTO, José, Op. cit., pp. 41-42.

128. Ibidem.

129. Ibidem

130. Con respecto al pensamiento kelseniano acerca de la paz en la teoría pura del derecho, observa Juan José Gil Cremades una contradicción: "Por un lado era la paz algo esencial al Derecho, pasando del valor a la validez. Cabía el peligro de un formalismo ético. La aproximación al pax est quaerenda del De Cive, de Hobbes, era flagrante. Por otro lado, se daba una contradicción en la depuración científica intentada al admitir un criterio inverificable de valor como un criterio verificable de validez". Considera J.J. Gil Cremades que en la segunda edición de la Reine Rechtslehre vuelve a los postulados de la teoría: "En la norma fundamental del Derecho internacional no se afirma un valor trascendente, sea éste, incluso el de la paz. El Derecho internacional y -supuesto su supremacía- los particulares órdenes jurídicos a él subordinados, son válidos no porque realicen el valor de la paz. Esos ordenamientos pueden realizar ese valor siempre y cuando sean válidos, y son válidos cuando se presuponga la norma fundamental, que 
que obligatoriamente se someterían los Estados contratantes para resolver sus conflictos con arreglo a determinadas condiciones, como señala en su obra Peace Through Law, de 1944. Esta solución propuesta por Kelsen, al igual que otros intentos de otros ius-filósofos (en el caso de Del Vecchio la confianza se puso en la Organización de las Naciones Unidas como órgano supranacional y tutelador de derechos) ponen de relive la parcial y deficiente existencia de un verdadero orden jurídico que norme las relaciones humanas en el ámbito que llamamos internacional y sirva de garantía a la paz ${ }^{131}$. Se trata en definitiva de una deficiencia que, incluso hoy en día, a pesar de los mecanismos e instituciones internacionales creadas al respecto para paliarla, no ha conseguido ser superada.

VI. Cabe preguntarse si en la actualidad la balanza se inclina a favor de la guerra o de la paz ${ }^{132}$. En este sentido, advierte Cotta que desde 1945 hasta hoy el mundo no ha gozado de paz, probablemente, ni siquiera durante un año. Además, los combates locales, salvo alguna excepción, no son posibles sin acuerdos o alianzas internacionales; éstos, por una parte, aseguran los

la praxis entre Estados establece como situación normativa de hecho, y de cuyo contenido participen las normas así determinadas" ( $P a z$ y "teoría pura" del Derecho. En: "Derecho y paz. Op. cit.," pp. 202-204).

Antonio Truyol y Serra también destaca la labor realizada por Kelsen al intentar dar un giro a la doctrina del bellum iustum, explicándola fuera de la anterior perspectiva iusnaturalista: "tales esfuerzos se diferencian de la doctrina clásica de la guerra justa porque según ellos (se refiere a L. Strisower y H.Kelsen) sólo es lícita la guerra como reacción contra una violación del derecho internacional positivo, sin consideración alguna de criterios materiales de justicia; lo cual equivale en la práctica a la protección incondicional del status quo histórico que puede ser injusto. La doctrina clásica de la guerra justa, en cambio, entiende por violación del derecho una violación del derecho natural o del derecho internacional positivo justo, es decir, del que concuerda con el natural" (Ordenamiento jurídico y paz internacional. En: "Derecho y paz. Op. cit.," p. 54).

131. DELGADO PINTO, José, Op. cit., pp. $42-43$.

132. No nos detenemos en la violencia que no se ha plasmado en conflictos bélicos, es decir, en aquella que constituía el reflejo de profundos cambios ideológicos. Así por ejemplo C. Marx, consciente de la miseria del proletariado, es partidario de una revolución dotada de base científica. Se trata de una revolución que no tiene nada que ver con la pasión, ni con razones morales o religiosas. Esa revolución del proletariado frente al capitalismo intenta luchar contra las leyes del materialismo histórico.

Jean Paul Sartre, al igual que otros representantes del existencialismo, también aplica la violencia aunque de diverso modo, al ver la raíz del sufrimiento humano en la presencia de los otros: "cada uno descubría a los demás como competidores en el disfrute de una materia que "no alcanzaba para todos" $y$, por consiguiente, tenía que verlos con el peligro del propio perecimiento, y la sociedad o colectividad de individuos era entendida como la "imposibilidad de coexistencia". Por ello, el hombre perdía su propia condición de hombre, se alienaba y se convertía en . inhumano, extraño y más peligroso que ningún otro animal. Incluso esta concepción puede recordarnos en cierta manera la de Hobbes, aunque éste último situaba la causa de los males sociales en los hombres mismos, a diferencia de Sartre que lo coloca en una circunstancia exterior y contingente: la escasez de la materia que necesitan para satisfacer sus necesidades. 
modernos y costosos suministros bélicos y los apoyos diplomáticos y, por otra, impiden que se sobrepase el umbral termonuclear ${ }^{133}$. Los conflictos bélicos contemporáneos se hallan sujetos a la fanatización ideológica y, en numerosas ocasiones, a la utilización de la guerrilla. Por todo esto, se pone de manifiesto que, por una parte, la violencia bélica no ha disminuido como se esperaba en el siglo XIX sino que se ha difundido ampliamente, a pesar de no haber alcanzado el climax de la total violencia termonuclear; por otra parte, cuando surge la guerra, las hostilidades se introducen en todos los estratos de la sociedad ${ }^{134}$.

Aprovechándose de la necesidad de "disuadir al otro", para eliminar el miedo ante una situación de ataque se mueven muchos intereses económicos y tecnológicos, tales como las industrias de armamento. La justificación de cara a la opinión pública de en qué y porqué se detraen esas importantes cantidades del presupuesto para utilizarlas en esa "carrera de armamentos", se basa en la falsedad de presentar al otro como malo, mientras uno se ve a sí mismo como perfecto. Se trata de la llamada "hipótesis de lo peor": los otros son más poderosos y están dispuestos a destruirnos ${ }^{135}$.

A la vista de lo expuesto, cabría considerar que el discurrir de la historia no ha logrado acabar con la violencia y lucha entre los hombres sino que, por el contrario, ha coadyuvado mediante los progresos de la técnica, a lograr armas cada vez más refinadas para lograr hacer una "más y mejor" guerra. De ahí que la opción por la paz sea la postura adoptada por la mayoría de los convenios, tratados, instituciones, $u$ otros entes, bien sea a nivel político, económico o religioso. Ello nos lo confirman las dos posturas que respectivamente sustentan la Constitución española de 1978 y la Iglesia católica, como vamos a analizar seguidamente.

1) De los cuatro plateamientos de Bobbio sobre el tema de la paz en relación con la guerra: belicismo absoluto (la guerra antítesis del derecho), pacifismo absoluto (la guerra antítesis del derecho), pacifismo moderado (la guerra objeto de regulación jurídica) y la guerra objeto de la teoría iusnaturalista, entendemos, como R. Soriano, que hoy en día el Estado sólo puede

133. Entiende Cotta que todos los avances conseguidos por el hombre en el campo científico y técnico, deben ser utilizados con las máximas precauciones: es lo que denomina la sfida tecnologica: "il giurista (...) ciò è luminosamente palese in quel suo secolare atteggiamento di diffidenza verso il Potere che lo ha spinto a proclamarne prima la subordinazione alla legge naturale, poi alla consuetudine, ai diriti dell'uomo, infine al principio di legalità, alla costituzione e alla stessa logica interna dell'operare giuridico. Per allontanare lo spettro della violenza e della tirannide, il giurista ha diviso il Potere, lo ha reso responsabile, ne ha organizzato il controllo" (La sfida tecnologica. 4ª ed., Bologna, Il Mulino,1971, pp. 189-190).

134. COTTA, Sergio, Perchè la violenza? Una interpretazione filosofica, pp. 45-47. (Las raices de la violencia, pp.64-66).

135. BALLESTEROS, Jesús, Paz, desarme, libertad: obstáculos económicos e ideológicos. En: “A.F.D.”. T. II (1985) p. 70. 
escoger un pacifismo moderado o limitado participando en el ius belli o reglamentación de la guerra entre los Estados; incluso, cuanto más pacifista sea el Estado, tanto más le interesa participar en ese Derecho internacional de la guerra porque el pacifismo o belicismo absolutos cada vez están más lejos de las posibilidades reales de un Estado contemporáneo ${ }^{136}$.

La Constitución española, como norma fundamental del Estado, debía plantearse también el tema de la paz dado que cualquier Constitución debe tener en cuenta la doble vertiente de la paz: como valor necesario en las relaciones entre los pueblos y como valor interno-estatal, debiendo figurar ambas entre los fines primordiales del Estado. Sin embargo, hay que advertir que nuestra Constitución no hace grandes referencias a la paz en contraste con otras Constituciones ${ }^{137}$, sin que ello signifique que la paz no reciba un tratamiento constitucional. La paz sí se encuentra presente en nuestra Constitución, aunque pocas veces se haga alusión directa a la misma más que en aspectos puntuales. Así, la Constitución se acoge a este sistema de pacifismo moderado consciente de que un extremo pacifismo dificilmente podría llevarse adelante en el terreno práctico ${ }^{138}$.

En concreto, nuestra Constitución alude expresamente a la paz en tres momentos diferentes de su texto: Primero, en el Preámbulo, al indicar como uno de los propósitos básicos de la nación española su voluntad de "colaborar en el fortalecimiento de unas relaciones pacíficas y de eficaz cooperación entre todos los pueblos de la tierra". Segundo, en su parte dogmática, al iniciar el Título I en el que indica que la dignidad de la persona, los derechos inviolables que le son inherentes, el libre desarrollo de la personalidad, así como el respeto a la ley y a los derechos de los demás "son el fundamento del orden político y de la paz social" (art. 10.1). Y, tercero, en la parte orgánica, al establecer en el Título II, entre las funciones de la Corona que: "Al Rey corresponde, previa autorización a las Cortes Generales, declarar la guerra y hacer la paz" (art. 63,3).

Estas referencias constitucionales a la paz pueden dar la impresión de que son un tanto dispares ya que la primera y la tercera se refieren a la paz en su proyección internacional y la segunda se enmarca en el ámbito de los

136. SORIANO, Ramón, Op. cit., p. 134.

137. Así por ejemplo, la actual Constitución italiana, que data de 1947, recoge esta referencia a la paz en su artículo 11, incluyéndolo entre los Principi Fondamentali: "L'Italia ripudia la guerra come strumento di offesa alla libertà degli altri popoli e come mezzo di risoluzione delle controversie internazionali; consente, in condizioni di parità con gli altri Stati, alle limitazioni di sovranità necessarie ad un ordinamento che assicuri la pace e la giustizia fra le Nazioni; promuove e favorisce le organizzazioni internazionali rivolte a tale scopo" (Costituzione della Repubblica Italiana. Ed. Bignami, 1993, p. 25).

Es posible que esta amplia referencia obedezca a que la Constitución date de 1947, poco tiempo después de la segunda guerra mundial, cuando aún Italia se estába recuperando de las secuelas de tal conflicto bélico.

138. Cfr. SORIANO, Ramón, Op. cit., p. 135. 
fines y valores del sistema político social interno. Por otra parte, su aparente significación contradictoria puede también verse en la medida en que si fuera firme la convicción, formulada en el Preámbulo constitucional, del fortalecimiento de unas relaciones pacíficas entre todos los pueblos, resultaría innecesario que el Rey tuviera que recurrir a declarar la guerra y, por ello, a hacer la paz, según el artículo 63,3. Con todo, no encontramos justificada esa pretendida acusación de heterogeneidad ni la del supuesto caracter contradictorio de las remisiones a la paz por parte de nuestro texto constitucional ${ }^{139}$.

De ahí que la posibilidad de "declarar la guerra" a que hace referencia el artículo 63,3, deba entenderse en un sentido restringido ${ }^{140}$, sólo para el caso límite de un supuesto de legítima defensa ${ }^{141}$. Es por ello que la Consti-

139. Participamos de la opinión sustentada por A.E. Pérez-Luño a este respecto cuando considera que el hecho de que del artículo 63,3 quepa entender la posibilidad de que el Estado español pueda entrar en un conflicto bélico, en nada afecta al firme propósito constitucional, considerado como valor básico ya desde su Preámbulo, de comprometerse en el logro de unas relaciones pacíficas con todos los pueblos de la tierra. Es precisamente este valor, contenido en el Preámbulo, el que orienta la interpretación del artículo 63,3 y evita cualquier posible antítesis entre el contenido de ambos preceptos ( Cfr. La paz como valor constitucional. En: “A.F.D.”. T.II (1985) pp. 126-127).

140. Para A. Ruiz Miguel, si bien la doctrina del belicismo absoluto puede esconderse detrás de las verdaderas intenciones a las que a veces parece responder la práctica de la conducta de los Estados, sin embargo, precisa que no es casual que sea la doctrina del belicismo relativo -bien en la versión de la guerra justa para los Estados occidentales, bien en la versión de la guerra revolucionaria para los Estados del socialismo real- la que declaran seguir las superpotencias. Remiten la razón justificativa de las guerras al criterio de la justicia, lo cual no impide que ésta sea interpretada de diversa forma por una y otra doctrina. Destaca Ruiz Miguel que la doctrina oficial de los grandes Estados actuales aparece como belicista relativa, a diferencia de las exigencias interpretativas del Derecho internacional contemporáneo que parece sugerir mas bien un cambio de punto de vista desde la doctrina tradicional del belicismo relativo a la del pacifismo relativo (Cfr. Op. cit., p. 107).

141. Ante la dicotomía del belicismo relativo y del pacifismo relativo surge la inevitable cuestión de cuál sea el criterio que permita diferenciar adecuadamente uno y otro. Señala A. Ruiz Miguel que para quien la paz no constituya un valor predominante cuando entra en conflicto con otros valores, el recurso a la guerra resultará justificado en muchos casos. En cambio, quien se interese por dar una especial relevancia al valor de la paz -aunque no prioridad completa, que sería el punto de vista del pacifismo absoluto-, considerará que la guerra sólo puede quedar justificada o excusada en determinados casos especiales. Es por ello que la línea fronteriza entre uno y otro se encuentra entre las guerras ofensivas y defensivas. "Siempre que la legítima defensa se entienda en un sentido estricto, puede sostenerse que entran en el marco del pacifismo relativo aquellas posiciones que admiten sólo la legítima defensa como razón que puede excusar o justificar la participación en una guerra, en tanto que entrarían en el marco del belicismo relativo las posiciones que justifican o excusan esa participación tanto por razones de legítima defensa, cuanto por otras razones más o menos relacionadas con ella, como la reparación de un agravio, la reclamación de un derecho o la prevención de un ataque posible, aunque no, desde luego, el afán de conquista o la búsqueda de la hegemonía, que son expresiones del belicismo absoluto" (Ibidem, pp. 101-102). 
tución española entraña una concepción inequívoca a favor de la paz ${ }^{142}$, bien sea en las relaciones internacionales como en la convivencia de los ciudadanos; pero en ambos aspectos, da la impresión de que la referencia constitucional resulta excesivamente escueta. Habría sido más deseable que el compromiso desarrollado por el Estado a favor del mantenimiento de la paz internacional se hubiera acompañado de fórmulas más concretas. Esto habría supuesto que el propósito contenido en el Preámbulo constitucional se hubiera acompañado de fórmulas de autolimitación de la soberanía nacional y, con respecto a la paz como valor interno-estatal, que hubiera recibido un tratamiento prioritario constitucional, como otros valores jurídicos (como hemos visto, ni tan siquiera se encuentra recogida en el artículo 1,1 de la Constitución) ${ }^{143}$.

2) Han sido numerosas y reiteradas las muestras que la Iglesia católica ha dado a lo largo de la historia con la intención de justificar el papel que podía y debía ejercer en la obra trascendental de la consolidación de la paz. Para ello se basaba en la supranacionalidad de la iglesia al ser indivisible y universal. De ahí que considerara que todo intento de cohesión social levantado al margen de la iglesia estába condenado a deshacerse. Los diversos Pontífices, a través de sus mensajes, encíclicas y por medio de los Concilios, han intentado transmitir este sentir ${ }^{144}$.

El pontificado de Benedicto XV (al desarrollarse en su inicio al compás de la primera conflagración mundial) representa un importante intento de reconciliación cristiana entre los pueblos. Su encíclica Ad Beatissimi es un llamamiento a la paz. Entre las causas de guerra que hay que desterrar cita

142. Considera A.E. Pérez-Luño, partiendo de una conocida tipología que distingue tres tipos de paz $\left(1^{\circ}\right.$ la de potencia, que se funda en la hegemonía o en el dominio; $2^{\circ}$ la de impotencia, que se basa en el "equilibrio del terror"; y $3^{\circ}$ la de satisfacción, fundamentada en la confianza recíproca y en la mutua cooperación) que la Constitución española puede concebirse como pacifista, en la medida en que no supone la defensa de una paz cualquiera que pudiera encontrarse basada en el dominio o en el terror; al contrario, representa una opción en favor de una paz de satisfacción, basada en la decisión consciente hacia el fortalecimiento de las relaciones de cooperación pacífica entre todos los pueblos (Cfr. Op. cit., pp. 129-130).

143. Nos adherimos a la crítica manifestada en este mismo sentido por R. Soriano (Cfr. Op. cit., pp. 160-161).

144. Destaca A. Ruiz Miguel la tendencia existente en algunas doctrinas de ofrecer un concepto positivo de paz ("positivo" referido en este caso tanto a un sentido lógico como valorativo), tendencia especialmente evidente en la tradición judeo-cristiana. Así, considera que el cristianismo tiende a explicar la paz como una de las manifestaciones del amor, cuyo fin es buscar la unión entre los hombres. En el contexto de esta tradición, destaca Ruiz Miguel varios documentos pontificios contemporáneos de la Iglesia católica que insisten en que la paz no se consigue más que a través de la instauración del orden establecido o querido por Dios (Pacem in terris, Populorum progressio y, especialmente, Gaudium et spes, que se opone a la definición meramente negativa de la guerra y define la paz basándose en ideales de justicia y amor) (Cfr. $O p$. cit., pp. 51-52). 
el olvido de la caridad cristiana, el desprecio de la autoridad, la injusticia de las luchas sociales y la codicia de los bienes temporales provocada por el materialismo. Benedicto XV condenó sin reticencias la guerra calificándola de "matanza inútil" y "crimen odioso", indigno de los pueblos cristianos. Para remediar esta situación señala la necesidad de restablecer el culto a la caridad cristiana en todo el amplio campo de las relaciones humanas, el reconocimiento del origen divino de toda autoridad y la obligatoriedad moral de la obediencia civil así como el considerar la justicia como base y requisito de toda reivindicación social. Defiende además la posición de estricta imparcialidad de la Iglesia dado que ésta no puede ponerse al lado de las partes beligerantes porque se encuentra por encima de ellas, y debe mantener unidos a los que la guerra mantiene separados ${ }^{145}$.

De forma semejante se expresaba en su Exhortación a los gobernantes de las naciones en guerra, Dès le dèbut ${ }^{146}$ y en la encíclica Pacem Dei ${ }^{147}$. En la primera defendía la supremacía del derecho sobre la violencia de las armas. El desarme, el arbitraje, la libertad de las vías de comunicación, el problema de las reparaciones de guerra, la liberación de los territorios ocupados y el arreglo pać́fico de los litigios territoriales son los puntos que el Papa expone como requisitos para el establecimiento de una paz justa para todos. En la segunda, se ofrece a aceptar la participación efectiva de la Santa Sede en la obra de creación de la Sociedad de Naciones (Benedicto XV proclamó la necesidad de establecer "una sociedad, o mejor dicho, una familia de naciones") aunque esta ayuda fue finalmente rechazada.

El pontificado de Pío XI estuvo caracterizado por la sorda amenaza de una nueva guerra mundial, acentuando la inminencia del peligro el totalitarismo y la fuerte crisis económica. Ante esta situación, Pío XI reiteró la tesis, ya expuesta por Benedicto $\mathrm{XV}$, de la ilicitud moral de toda guerra ofensiva. Se hacía necesario evitar a toda costa la guerra y mantener la paz.

Lo que en Pío XI fue una amenaza se convirtió en una triste realidad para su sucesor, Pío XII. Su encíclica Summi Pontificatus critica la guerra por la repercusión que ésta podía tener en dos planos principales: el nacional y el internacional. En lo nacional, consideraba que el gran pecado del totalitarismo era la destrucción de los derechos de la persona humana. En lo internacional, el gran error del Estado totalitario era la negación drástica de

145. Carta Encíclica Ad Beatissimi (La guerra mundial y sus causas) (1-23). En: "Doctrina Pontificia. T.II. Documentos Políticos". Ed. preparada por José Luis Gutiérrez García. Madrid, B.A.C, 1958 , pp. $437-462$.

146. El día 1 de agosto de 1917 enviaba Benedicto XV la nota Dès le dèbut a los gobiernos de las naciones beligerantes, señalando como bases de negociación una serie de consideraciones prácticas cuya aceptación supondría el fin de la guerra y el establecimiento de una paz justa y duradera. En: "Op. cit.", pp. 463-468.

147. Carta Encíclica Pacem Dei (1-16). En: “Op. cit.”, pp. 469-483. 
la comunidad internacional de los pueblos ${ }^{148}$. En el discurso In questo giorno $^{149}$, Pío XII propone examinar los objetivos justificables de la guerra a la vez que considera imprescindible determinar los puntos fundamentales de una paz justa ${ }^{150}$, eliminando los graves obstáculos que se opongan a la creación de una paz justa internacional.

En su Sermón pronunciado en la vigilia de Navidad de 1945, Negli ultimi ${ }^{151}$, nos presenta tres presupuestos que considera esenciales para llegar a la paz: el de la necesaria colaboración de todos los pueblos de forma que las resoluciones políticas y económicas se orienten al bien común de todas las naciones; el de que es ilícito deformar a sabiendas la opinión pública y el de que hay que acabar con el totalitarismo porque el señor del mundo no es el Estado ni los grupos de intereses. Reclama que hay que volver a un verdadero cristianismo en el Estado y entre los Estados ${ }^{152}$.

Después de las dos conflagraciones mundiales se sucedieron numerosos intentos en el orden político, internacional, etc. para lograr la unificación europea y la paz en el mundo. En el discurso La paz internacional y la guerra fría $^{153}$, Pío XII reconoce que la Iglesia católica trabaja por la paz pero que sin ayuda no puede conseguirlo. Recuerda que hay que tener presente que las generaciones actuales no son responsables del pasado y que el ciudadano no es responsable muchas veces de las decisiones estatales. Convenía distinguir entre los verdaderos culpables y el pueblo en general. De ahí que, entre las garantías para un porvenir pacífico señale la justicia objetiva, la misma medida para lo nacional y para lo extranjero, la estima recíproca y el respeto a los derechos de los demás pueblos.

Con respecto a la guerra fria ofensiva, entiende que debe ser condenada absolutamente por la moral. Pero si se produce, el atacado o los atacados pacíficos tienen no solamente el derecho, sino también el deber de defenderse. "Ningún Estado o ningún grupo de Estados puede aceptar tranquilamen-

148. Carta Encíclica Summi Pontificatus (27-47). En: “Op. cit., pp. 768-778.

149. Sermón pronunciado en la víspera de Navidad, el día 24 de diciembre de 1939. En: "Op. cit., pp. 801-813.

150. Como puntos fundamentales de la paz destaca: $1^{\circ}$ Independencia garantizada de todas las naciones, grandes y pequeñas. $2^{\circ}$ Importancia fundamental del desarme mutuo y progresivo. $3^{\circ}$ Necesidad de instituciones jurídicas para garantizar el fiel cumplimiento de los tratados de la paz y para revisarlos cuando fuera conveniente. $4^{\circ}$ Respeto a las justas exigencias de las naciones, pueblos y minorías étnicas. $5^{\circ}$ Revigorizar el espíritu de responsabilidad, de justicia y de amor, que es el único que puede dar vida a la letra muerta de los tratados internacionales (Cfr. In questo giorno (4-19). En: “Op. cit.”, pp. 809-811).

151. Es especialmente significativo este sermón porque fue dado en la vigilia de Navidad el 24 de diciembre de 1945, cuando acababa de terminar la guerra. De ahí que Pío XII se pregunte: “¿La paz de la tierra? ¡No, sino solamente la "posguerra", expresión dolorosa e incluso demasiado significativa" (Negli Ultimi. En: "Op. cit.", p. 902).

152. Cfr. Op. cit., pp. 900-910.

153. Discurso a los asistentes al Congreso Internacional de Pax Christi celebrado en Asís, el 13 de septiembre de 1952. (Cfr. Op. cit., pp. 996-1001). 
te la esclavitud política y la ruina económica. Por el bien común de sus pueblos deben asegurar su propia defensa" ${ }^{154}$.

Juan XXIII, en la encíclica Pacem in terris, no trata directamente el tema de la guerra porque su objetivo es la paz entre los hombres y entre los pueblos pero, al exponer los principios de la paz, no puede por menos de condenar el fenómeno bélico. El cristianismo, aunque acepta la licitud del recurso a las armas en ciertas condiciones y admite la posibilidad de la guerra justa, no puede llamarse belicista ${ }^{155}$ porque aquí no existe exaltación ni apología de la guerra ${ }^{156}$. El pensamiento cristiano por el contrario, se centra

154. Op. cit., p. 1000.

155. Partiendo de que la guerra implica una forma colectiva del uso de armas y, a la vez, un fin colectivo, cabe diferenciar, en líneas generales, dos actitudes ante la guerra: la del belicismo y la del cristianismo. En la primera no se defiende sólo su licitud en determinadas circunstancias sino que se hace una exaltación de la misma. Se considera que la guerra es una ley universal y necesaria de la naturaleza, ley superior a la voluntad humana y, en consecuencia la guerra no es un asunto de caracter moral sino que por el contrario, es una ley buena ya que a pesar de las grandes destrucciones que produce, provoca el progreso y bienestar de la humanidad y evita el estancamiento.

Gregorio Rodríguez de Yurre considera que el belicismo es una corriente que brota de diversas fuentes, como: $1^{\circ}$ ) Ideas políticas: se trata de un belicismo político que deriva de una determinada concepción del Estado, especialmente de la filosofía política hegeliana, donde se dibuja un Estado metamoral, animado de la concupiscencia del poder y que considera la guerra como su profesión. $2^{\circ}$ ) Ideas científicas: ideas especialmente recogidas de la ciencia evolucionista, como la de Darwin. La guerra sería una ley biológica impuesta por la naturaleza para lograr el progreso y evolución de la humanidad. $3^{\circ}$ ) Ideas jurídico-morales: el positivismo jurídicomoral niega la existencia de una ley natural, de un derecho natural. De aquí viene la divinización de la voluntad humana. De ahí también que se haya perdido la fe en la fuerza de la ley y del derecho para gobernar a los hombres y se haya admitido la fe en la ley de la fuerza. $4^{\circ}$ ) Ideas económicas, como las de Marx. La presión económica conduce a la presión militar. La guerra no es una ley universal de la naturaleza, sino una ley universal del mundo capitalista (Cfr. Actitud cristiana ante la guerra. En: "Comentarios a la Pacem in terris". Madrid, Instituto Social León XIII. B.A.C., 1963, pp. 459-460.

Concluye Rodríguez de Yurre considerando que el belicismo equivale a la negación del espíritu cristiano y que en no pocos casos, el belicismo se manifiesta más como un fanatismo que como un sistema racional de ideas

156. Hay otros muchos filósofos que a lo largo de la historia se han ocupado del tema de la guerra y a los que, dado lo limitado de nuestro trabajo, no hemos hecho referencia. Entre ellos, Hegel es otra de las fuentes importantes del moderno belicismo. A su parecer, el Estado es Dios en medio de los hombres. Esta divinización sitúa al ente político en un plano trascendente, superior al orden moral y de ahí que el Estado no pueda estar sometido a códigos de moralidad, los cuales son válidos tan sólo para la dirección de la conducta individual. Un nivel es en el que se mueve el ciudadano ordinario y otro, el de la política, en el que reina la voluntad del Estado. Este Estado divinizado no está sometido a ninguna norma de derecho que sea superior a la voluntad de intereses. A la vez, la esencia del Estado es el poder y la gloria militar de la hegemonía mundial. Existe, por consiguiente, una tendencia natural a la guerra, la cual es el gran instrumento de selección de los pueblos y Estados. La guerra es ley universal necesaria, encarnación de lo divino, sentencia inapelable de Dios o del Espíritu del mundo, ley buena de la que depende el progreso de la humanidad. 
en la paz y en los medios para lograrla. Por todo esto, la encíclica Pacem in terris recomienda que cese la carrera de armamentos y que se proscriban las armas nucleares con el fin de lograr un desarme gradual ${ }^{157}$. Asimismo, considera que las diferencias internacionales no deben resolverse por la fuerza de las armas sino por medio de convenios. La guerra ya no es un medio apto para resarcir el derecho violado ${ }^{158}$.

Son especialmente significativas las conclusiones del capítulo quinto sobre la paz y la guerra de la constitución Gaudium et spes, promulgada por el Concilio Vaticano II. En estas se pone el acento más que en los principios, en las acciones que deben emprenderse inmediatamente para limitar los conflictos y construir la paz $^{159}$. Se parte de que la paz no es la simple ausencia de guerra ni tampoco el mero equilibrio de fuerzas en contraste. Los hombres, en cuanto pecadores, quedan siempre bajo la amenaza de la guerra; pero, en cuanto vencedores del pecado, vencen también la violencia. Por ello, frente a la extensión de la guerra y de sistemas bélicos inadmisibles, el Concilio llama la atención sobre el valor inmutable del derecho natural, de gentes y de sus principios universales. A la vez, destaca la importancia de los tratados internacionales que tienden a hacer menos inhumanas las acciones militares. Considera conforme a equidad las leyes que prevean el caso de aquellos que por motivos de conciencia rehusen el uso de las armas, aceptando en compensación, cualquier otra forma de servicio. Sin embargo, considera siempre digno de elogio el que sirve a su patria en el ejército ${ }^{160}$.

También Nietzsche es uno de los grandes odiadores del cristianismo: despreció el espíritu evangélico y maldijo las virtudes cristianas de la fraternidad universal, de la caridad, la mansedumbre y la bondad. Oponiéndose a éstas, Nietzsche sitúa al superhombre, el ser cruel con fines de conquista del poder y dominio. Considera que en este mundo no existe más ley que la fuerza y la guerra sin piedad (En Zaratustra aconseja querer la paz como medio para nuevas guerras. Defiende que una paz corta es mejor que una paz larga. Y no aconseja el trabajo, sino la gue-

rra). Lo normal, para Nietzsche, era la guerra y lo anormal la paz (Cfr. Ibidem, pp. 455-457).

157. Cfr. Carta Encíclica Pacem in terris (109-119). En: "Cinco grandes mensajes". Edic. preparada por J. Iribarren y J.L. Gutiérrrez García. Madrid, B.A.C., 1967, pp. 120-122.

158. Cfr. Pacem in terris (126-129). Ibidem, pp. 124-125.

159. Señala L. Pereña Vicente en su comentario a la constitución Gaudium et spes: "Pero tampoco el texto tiene un caracter "profético", como deseaba el grupo más progresivo del concilio. Muchos padres conciliadores alimentaban la esperanza de que el concilio pondría solemnemente la guerra fuera de la ley y condenaría sin restricciones las armas atómicas. Pero no hizo ni lo uno ni lo otro" (La construcción de la paz internacional. En: "Comentarios a la constitución Gaudium et spes sobre la Iglesia en el mundo de hoy. Concilio Vaticano II". Edic. dirigida por A. Herrera Oria. Madrid, B.A.C., 1968, p. 579).

160. Cfr. Gaudium et spes (77-79). en: "Op. cit.", pp. 352-354.

Surge aquí la controvertida objeción de conciencia a la realización del servicio militar, cuestión en la que no entramos porque desbordaría los límites que nos hemos propuesto (Ver L. Prieto Sanchís, La objeción de conciencia como forma de desobediencia civil al derecho. En: "Sistema" 59 (1984) pp. 41-62; J.M. Rojo Sanz, Monopolización del poder, objeción de conciencia y consecución de la paz. En: “A.F.D.”. T. II (1985) pp. 97-106; M. Gascón y L. Prieto, Los 
Se sigue admitiendo la legítima defensa como causa legítima de guerra. "Mientras exista la guerra y no haya autoridad internacional competente, no podrá negarse el derecho de legítima defensa". Pero diferencia el servirse de las armas para defender los justos derechos de los pueblos, y el imponer las armas por el propio dominio sobre otras naciones. Además, cuando se ha desencadenado una guerra, sostiene que no todo resulta lícito entre las partes que entran en conflicto ${ }^{161}$.

Es objeto de particular preocupación para la Iglesia los medios modernos mediante los cuales se hace la guerra porque podrían desencadenar una guerra total. El Concilio la rechaza porque excede del límite de la legítima defensa, que es el admitido para justificar una guerra, para hacer una guerra justa. Se opone también a la carrera de armamentos, aunque éste sólo tenga por objeto disuadir de cualquier posible agresión. Considera que no resulta una vía segura para conservar la paz.

Entiende el Concilio que es necesaria la existencia de una autoridad universalmente reconocida por todos y con medios eficientes para garantizar a todos los pueblos la seguridad y la tutela del derecho ${ }^{162}$. En el tiempo de preparación para alcanzar este objetivo, recomienda un desarme no unilateral sino común, basado no en el terror de las armas sino en acuerdos mutuos y con seguras garantías ${ }^{163}$.

Más recientemente, Juan Pablo II en Solicitudo rei socialis manifiesta su inquietud por las consecuencias que pueda acarrear la producción y comercio de las armas. Defiende que si el "desarrollo es el nuevo nombre de la paz", la guerra y los preparativos militares son el mayor enemigo del desarrollo integral de los pueblos ${ }^{164}$. En Centesimus annus recuerda que la verdera paz no es resultado de la victoria militar sino algo que implica la superación de las causas de la guerra y la auténtica reconciliación entre los pueblos. Considera que la precariedad de la paz que ha seguido a la segunda guerra mundial ha desencadenado que muchos pueblos hayan perdido el poder de autogobernarse, encerrados en los confines opresores de un imperio a la vez que se trataba de destruir su memoria histórica y las raíces de su cultura; a

derechosfundamentales, la objeción de conciencia y el Tribunal Constitucional. En: "Anuario de Derechos Humanos" 5 (1988-1989) pp. 97-120; J. de Lucas, E. Vidal y M.J. Añón, La objeción de conciencia según el Tribunal Constitucional: algunas dudas razonables. En: "Revista General de Derecho" 520-521 (1988) pp. 81-95; A. Millán Garrido, La objeción de conciencia. Madrid, Tecnos, 1990; etc.).

161. Cfr. Gaudium et spes (79). Ibidem.

162. De forma semejante se había manifestado G. del Vecchio al confiar en la Organización de las Naciones Unidas (O.N.U.), como órgano supranacional y tutelador de derechos. (Cfr. Verso un diritto mondiale. En: "Parerga. Saggi filosofici e giuridici". T.I. Milano, Giuffrè, 1961, pp. 119-125).

163. Cfr. Gaudium et spes (80-82). Ibidem, pp. 355-359.

164. Cfr. Sollicitudo rei socialis (Preocupación por los problemas sociales). Séptima Carta Encíclica de S.S. Juan Pablo II. Ediciones Paulinas,1988, p. 40 y p. 20. 
ello hay que unir masas enormes de hombres que son obligados a abandonar su tierra y son deportados forzosamente y, también, la carrera desenfrenada de armamentos que absorbe los recursos necesarios para el desarrollo de las economías internas y para ayudar a las naciones menos favorecidas. Concluye que todos estos son síntomas de una situación de no-guerra pero sin poder llegar a definirla como paz auténtica ${ }^{165}$.

$$
* * * * *
$$

Sirva esta reflexión para dejar una puerta abierta a la "sociedad del género humano" donde ni tan siquiera haya necesidad de la guerra justa porque, como hemos podido comprobar, no existe acuerdo unánime acerca de lo que este calificativo signifique. Con todo, no faltarán aquellos que añoren la guerra, o al menos su posibilidad, por considerarla como sinónimo de una política viva y dinámica. Baste recordar el pensamiento smichttiano que consideraba que un mundo en el que se hubiera eliminado la posibilidad de la guerra sería un mundo sin política.

Sabemos que el derecho admite la fuerza pero ésta debe encauzarse dentro de unos límites. Como teóricos del derecho, defenderíamos que la paz (y el consiguiente pacifismo como actitud más propia) deberían de presidir cualquier tipo de sociedad pero también, como prácticos del derecho, somos conscientes de la imposibilidad de llevar a la práctica este ideal ${ }^{166}$. De ahí que aboguemos, como ya hemos manifestado anteriormente al ocuparnos de la Constitución española y su actitud ante la guerra, por un pacifismo

165. Cfr. Centesimus annus (La problemática social hoy). Novena Carta Encíclica de S.S. Juan Pablo II. Ediciones Paulinas, 1991, pp. 34-36.

166. Defiende E. Galán y Gutiérrez la tesis de que la guerra como fenómeno concreto no es nunca inevitable, de modo que su desencadenamiento y promoción depende de la libre resolución humana; además, considera que esta afirmación es compatible con la idea de la imposibilidad de abolir de manera radical las contiendas armadas entre Estados: "La paz misma es una manifestación de esa lucha esencial a la vida. Hay muchas luchas que crean: son las de la paz, y otras que destruyen, a las cuales llamamos guerra. Ninguna guerra concreta es por principio inevitable. Pero la guerra, en general, como fenómeno social, resulta de hecho absolutamente inabolible. Ingenuo y craso error es ser pacifista y balar bucólicamente la paz. Pero, en cambio, ser pacíficos constituye uno de los deberes primordiales de la vida y el ideal más bello de la humanidad (...) "Sed pacíficos incluso al luchar, a fin de poder llevar a los vencidos los beneficios de la paz. Pero sabed también -enseña San Agustín- que adonde el hombre va consigo lleva el principio de la lucha". Mas si la guera es inabolible, concluye Galán y Gutiérrez, los hombres deben esforzarse por reducir su frecuencia. La paz eterna es impracticable, como reconocía el propio Kant pero eso no impide, a juicio de Galán y Gutiérrez, el que debamos tender a acercarnos a ella progresivamente (Op. cit., pp. 139-140).

167. Para A. Ruiz Miguel, en la actualidad y por el peligro que podría entrañar una guerra nuclear, se rechaza no sólo el belicismo absoluto sino también el belicismo relativo, es decir, las tradicionales doctrinas de la causa justa y las más nuevas pero no tan diferentes doctrinas de la guerra revolucionaria. La actitud más admisible, a su juicio, parece ser la pacifista relativa, que 
moderado o relativo ${ }^{167}$ participando de la reglamentación jurídica de la guerra entre Estados.

No olvidamos tampoco el importante papel que en este entramado puede desempeñar la "sanción", como medida disuasoria frente a posibles peligrosas pretensiones o actuaciones por parte de algunos Estados. Somos conscientes de que sólo un pacifismo basado en el derecho sería eficaz, haciendo así posible la legítima defensa de los Estados frente a injustas agresiones por parte de otros. Otra actitud provocaría el resultado contrario a aquél pretendido por el pacifismo, desembocando en el triunfo de una violencia sin limitaciones ${ }^{168}$.

Nuria Belloso MARTIN
Universidad de Burgos

admite como única causa justa de participación en una guerra a la legítima defensa. Esta comprende la respuesta a una agresión en curso pero también como señala Ruiz Miguel, los siguientes supuestos: primero, el ataque que se anticipa a su vez a un ataque inminente y cierto; segundo, la punición de una agresión no concluida o que previene de una nueva agresión inminente y cierta; tercero, la defensa de terceros Estados agredidos en las anteriores circunstancias y, por último, la defensa de las intervenciones por razones humanitarias en guerras de liberación colonial y racista (Cfr. Op. cit., p. 286).

168. Así cabría citar, como expresa A. Ruiz Miguel, el pacifismo radical de quienes mantienen una posición de no violencia, sea pasiva o activa, que apela, antes que al derecho a no morir, al criterio de que se debe morir antes que matar. Pero no hay que olvidar que esta actitud puede desencadenar una situación moral y valorativamente reprobable -si por ejemplo diferenciamos entre matar y dejar morir- cuando la muerte de terceros es atribuible a la omisión de quienes están obligados a su defensa (Cfr. Ibidem, pp. 289-290). 